
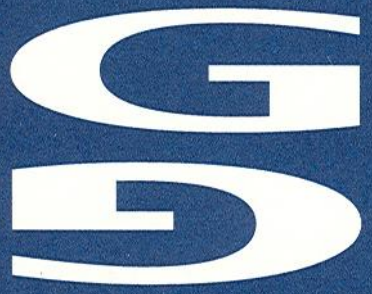

MAASTRICHT GRADUATE SCHOOL of GOVERNANCE

\title{
Exploring multi-dimensional wellbeing and remittances in El Salvador
}

\author{
Jessica Hagen-Zanker \\ Mirtha Rosaura Muñiz Castillo
}

Working Paper

MGSoG/2006/WP002

August 2006

Maastricht University

Maastricht Graduate School of Governance 


\section{Maastricht Graduate School of Governance}

The 'watch dog' role of the media, the impact of migration processes, health care access for children in developing countries, mitigation of the effects of Global Warming are typical examples of governance issues - issues to be tackled at the base; issues to be solved by creating and implementing effective policy.

The Maastricht Graduate School of Governance, Maastricht University, prepares students to pave the road for innovative policy developments in Europe and the world today.

Our master's and $\mathrm{PhD}$ programmes train you in analysing, monitoring and evaluating public policy in order to strengthen democratic governance in domestic and international organisations. The School carefully crafts its training activities to give national and international organisations, scholars and professionals the tools needed to harness the strengths of changing organisations and solve today's challenges, and more importantly, the ones of tomorrow.

\section{Authors}

Jessica Hagen-Zanker, PhD Fellow

Maastricht Graduate School of Governance

Maastricht University

Email: jessica.hagenzanker@governance.unimaas.nl

Mirtha Rosaura Muñiz Castillo, PhD Fellow

Maastricht Graduate School of Governance

Maastricht University

Email: mirtha.munizcastillo@governance.unimaas.nl

\footnotetext{
${ }^{a}$ We thank Prof. Lilian Vega, chief of the Economics department in Universidad Centroamericana "José Simeón Cañas" of El Salvador for her extensive support. We also thank Denis de Crombrugghe for helping us out on Stata problems and Alex HagenZanker for enlightening us on fuzzy sets. We are grateful to the participants at the Development Economics PhD Seminar on 14 October 2005 in The Hague for their useful comments. The usual disclaimer applies.
}

\section{Mailing address}

Universiteit Maastricht

Maastricht Graduate School of Governance

P.O. Box 616

6200 MD Maastricht

The Netherlands

Visiting address

Kapoenstraat 2, $6211 \mathrm{KW}$ Maastricht

Phone: +31433884650

Fax: +31 433884864

Email: $\underline{\text { info-gov@governance.unimaas.nl }}$ 


\begin{abstract}
El Salvador has experienced high and increasing migration outflows during the last three decades, fuelled by the civil war in the 1980s and currently by a lack of economic opportunities. In parallel, family remittances have grown to represent 16.1 percent of GDP in 2004. In this context, it is relevant to explore the wellbeing of individuals in households receiving remittances.

In this paper, we propose an alternative measure of multi-dimensional wellbeing based on the capability approach that focuses on functionings or achievements of individuals in valuable dimensions of life, such as "life and physical health" and "social relations". From the multipurpose household survey (EHPM), we select feasible indicators for these dimensions which we aggregated using the Fuzzy Sets theory.

We analyse wellbeing of different population groups in the selected dimensions of life. We find interesting differences in wellbeing between urban and rural households and male and female headed households.

Finally, we analyse wellbeing for individuals in households depending on migration and remittances status. Households that receive remittances do show higher wellbeing, and those that are non-poor and receive remittances perform better than all other groups. The difference is higher in the dimensions of "security, shelter and environment" and in social relations".

This is the first application of Fuzzy Sets theory to measure multi-dimensional wellbeing in El Salvador, based on the EHPM. We recommend the inclusion of additional indicators in the questionnaire and a further exploration of this method to assess wellbeing of different population groups in order to support a more precise definition of social protection policies.
\end{abstract}

Keywords: wellbeing, capabilities and functionings, migration, remittances, fuzzy sets JEL codes: F22, I31, I32, R20 


\section{Introduction}

This paper has two main goals: to apply the capability approach to a Salvadoran national household survey and to explore the nature of the interaction between multi-dimensional wellbeing and migration and remittances. For the latter, we focus on the wellbeing of individuals in households receiving remittances, not on the migrants.

We consider the capability approach suitable to assess wellbeing because it emphasises the difference between means and goals of development. It goes beyond approaches of material basic needs that characterise wellbeing by looking at different shortcomings (such as housing and education) and others that assess only monetary indicators. The capability approach aims to evaluate wellbeing by considering valuable dimensions of life (not only material, e.g. self-realisation) and differentiates between the actual achievements that individuals have (what they are or do), and the opportunities for reaching them. Because valuations are individually formed and based on multiple personal and contextual factors, this approach calls for a micro-level analysis. However, a challenge in this paper is to investigate to which extent we can apply the capability approach to the actual questionnaire used in the household survey, and to find plausible alternatives to overcome potential shortages.

A current multi-dimensional picture of wellbeing may signal opportunities for future improvements in wellbeing; for instance, better achievements in education and health would be associated with better life prospects in general. In the same way, migration is seen as a strategy for creating opportunities that otherwise would be not be accessible for many Latin American countries. Large parts of the population in El Salvador regard migration as the only way to improve their wellbeing and that of their families, and to build a safety net to cope with many risks (such as health care emergencies, lack of pension income for the elderly, natural disasters, etc.). In fact, some studies have found that families receiving remittances invested more in education and health than the others (Kandel, 2002, p. 10). We would like to explore to what extent families receiving remittances have different achievements in selected dimensions of life.

Below, we discuss the relevance of migration and remittances for El Salvador. 
Currently, approximately 2.8 million Salvadorans live abroad and most of them send remittances to their families. In per capita terms, El Salvador has the $2^{\text {nd }}$ place in the ranking of Latin American countries recipients of family remittances, ${ }^{1}$ following Jamaica (IADB, 2004). Remittances have grown steadily since 1980s from 790.10 million US\$ in 1991 to 2547.60 US\$ in 2004 and represent 16.1\% of GDP in 2004 (Central Bank of El Salvador, 2005). Remittances are the biggest source of foreign currency for El Salvador, much higher than international aid flows and private investment flows.

Migration in El Salvador began to increase during the civil war in the 1980s that forced many people to leave their country. However, when it ended, not all migrants returned due to the lack of economic opportunities and the strong links built in recipient countries (mainly U.S.). Natural disasters, like hurricane Mitch and 2001's earthquakes, have also affected this decision to return. The figure below depicts the long term trends in migration flows and shows how outflows during the recent decade exceed those of previous ones. Indeed, reasons for migration still exist. ASIPES (2002) found that the main were lack of jobs, poverty and self-realisation. ${ }^{2}$

\section{Flow of net migrants 1980-2004}

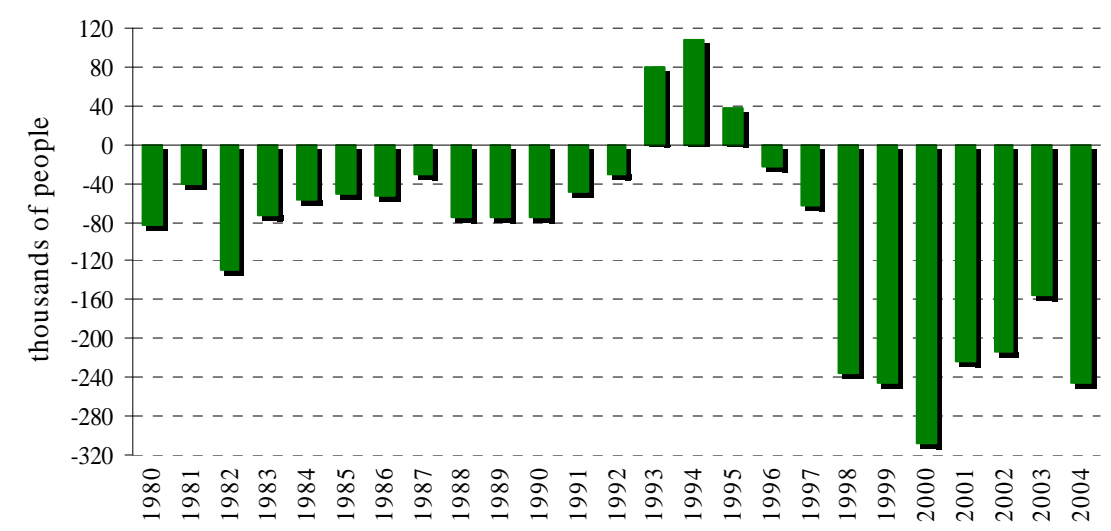

Figure 1 Flow of net migrants 1980-2004. Data source: SIEMMES-OIM, 2005.

\footnotetext{
1 "The portion of international migrant workers' earnings sent back to countries of origin" (IADB, 2004:9).

${ }^{2}$ When Salvadoran people were asked why they would not go back to El Salvador, 52 percent said that because there were no jobs, 32 percent that because the wages were too low and 22 percent that because they did not feel secure enough, as problems such as organised crime and gang delinquency remain (ASIPES, 2002).
} 
During the complete period 1980-2004, only 26.4 percent of the migrants were women, while during the period of the civil war this proportion was 43.5 percent. By 2003, urban and rural households were sending off almost the same percentage of migrants, approximately 17 percent, (SIEMMES-OIM, 2005), whereas before there were more urban migrants. In the same year, per capita remittances represented 37.6 percent of total per capita income. ${ }^{3}$

Regarding the characteristics of households receiving remittances, Andrade-Eekhoff (2003) analysed panel data from 1995, 1997 and 1999 and found that in rural areas, more dependency on remittances is found for single parents, female headed, more elderly members and fewer members of working age households. In 2003, 21.4 percent of households received remittances, as opposed to 14.4 percent in 1992-1993. In 2003, a slightly higher percentage of rural households received remittances (see table below).

Table 1 Households and remittances

\begin{tabular}{|c|c|c|c|c|c|c|c|}
\hline & \multicolumn{3}{|c|}{ 1992-1993 } & \multicolumn{4}{|c|}{2003} \\
\hline & \multicolumn{2}{|c|}{$\begin{array}{l}\text { Households receiving } \\
\text { remittances }\end{array}$} & \multirow{2}{*}{$\begin{array}{c}\text { Avg. amount / } \\
\text { household }\end{array}$} & \multicolumn{2}{|c|}{$\begin{array}{l}\text { Households receiving } \\
\text { remittances }\end{array}$} & \multicolumn{2}{|c|}{$\begin{array}{l}\text { Avg. amount / } \\
\text { household }\end{array}$} \\
\hline Area & Number & $\%$ tot $h h$ & & number & $\%$ tot $h h$ & colon & $U S \$$ \\
\hline Urban & 88,532 & 15.5 & C 770.6 & 207,923 & 21.0 & C $1,197.7$ & 163.8 \\
\hline Rural & 68,403 & 13.1 & C 526.4 & 133,041 & 22.2 & C $1,129.2$ & 140.4 \\
\hline Total & 156,935 & 14.4 & C 664.2 & 340,964 & 21.4 & C $1,354.4$ & 154.7 \\
\hline
\end{tabular}

Source: Kandel (2002) for years 1992-1993 and SIEMMES-OIM (2005) for year 2003.

As table 1 shows, the absolute average amount of remittances achieved by households has increased since the early 1990s from 664.2 colons (approximately 82 US\$) to 154.7 US\$ in 2003.

The dataset in this exploratory study comes from the multipurpose household survey EHPM (“Encuesta de Hogares de Propósitos Múltiples”) for the years 2001 to 2003 collected by DIGESTYC (the General Directorate of Statistics and Census of El

\footnotetext{
${ }^{3}$ Per capita remittances correspond to those households receiving remittances and per capita income to the overall population. This understates the remittance percentage of income for remittance-receiving households.
} 
Salvador). In the 2003 survey approximately $17,794^{4}$ randomly selected household heads in all of the fourteen departments of El Salvador were interviewed on a wide range of topics. These topics included the socio-demographic features of the household, extensive questions on the education and health of each household member and comprehensive information on the household accommodation, expenditures and remittances. The questions vary from subjective assessments (e.g. how is the quality of the nearest health centre?) to objective measurements (e.g. from which materials is your house constructed?).

It must be noted that the household data for year 2001 were collected after the 2001's earthquakes and therefore visible improvements in material conditions in the years thereafter are likely to be more related to reconstruction works financed with development aid. Consequently, we do not intend to analyse the temporal change in wellbeing but the current welfare conditions in three different years, exploring their links with the existence of remittances.

After this introduction, we present an alternative measure of wellbeing based on the capability approach in section 2 . We start by discussing its suitability and how to make it operational for our purposes, and then we build a list of dimensions for Salvadoran reality based on feasible indicators and present the Fuzzy Sets theory which is used to aggregate the indicators into dimensions. In section 3, we analyse achievements in those dimensions for different groups, including households with different migration and remittances status. Finally, in section 4, we present the main conclusions of this paper.

\footnotetext{
${ }^{4}$ The sample for 2001 and 2002 are 13,116 and 17,540 respectively.
} 


\section{An alternative measurement of wellbeing}

This section starts by explaining an alternative measurement of wellbeing based on the capability approach. We continue by selecting a list of functionings and indicators relevant to El Salvador from the EHPM household survey. This section finishes with a discussion of Fuzzy Sets theory, which we use in the aggregation of the wellbeing dimensions.

\subsection{Wellbeing and capabilities}

Development is more than economic growth or material progress. Development is about improving lives of human beings. UNDP (1990) explains that human development includes two elements: the formation of human capabilities, improved health, knowledge, skills, and the use people make of the acquired capabilities for leisure, productive uses, and cultural, social and political affairs. It "denotes both the process of widening people's choices and the level of their achieved wellbeing" (UNDP 1990, p. 10).

Capabilities can be understood as opportunities for doing or being things that people value, for example, being healthy, being well-nourished, being at peace with yourself, taking part in group decisions, expressing yourself politically, enjoying self-respect, etc. These things are the functionings. Hence, capabilities are the potential functionings that a person can achieve. Shortly, capabilities are the "ability to achieve" and functionings, the "achievements".

In the capability approach, the implicit assumption is that people can make choices. Consequently they choose the functionings depending on their objectives and personal values. In this sense, development is seen as the expansion of capabilities (or freedoms, Sen, 1999). However, in some cases, individuals cannot choose out of their capabilities set due to: (1) non-awareness (they do not realise what they can do individually or as a group), (2) lack of relevant information (due to power concentration of a few), or (3) a 
reduced ability to think clearly and make informed judgements about what they value. Most people living in long-term poverty would suffer of these failures. Their condition affects their social connectedness and self-esteem leaving them in a hopeless position to improve their situation. ${ }^{5}$

In this exploratory study we focus on wellbeing of Salvadorans based on the capability approach. We want to know more about the current life that Salvadorans are leading now, which is more relevant than assessing opportunities when living standards are below a given threshold (in this case, we can infer that current functionings are the best that people can do given the opportunities open to them) or the capacity to choose may be restricted. Other practical considerations also support our decision. ${ }^{6}$

An evaluation of wellbeing requires considering different dimensions of life that are valuable. We can start with basic or fundamental dimensions, and then continue with more context-specific ones. Once defined the functionings on these dimensions, the relevant step is to identify "certain minimally adequate levels (...) below which people count as being scandalously deprived" (Sen 1993, p. 41).

Defining these levels is not as straightforward as drawing an income-based poverty line and identifying those with less income as poor. The main reason for this difference is that different people can achieve different functionings with the same amount of money. What an individual can do with the money or other resources depends on how he or she converts these resources into functionings. This process, shown in figure 2, depends on the conversion factors, which are personal (physical condition, metabolism, age, gender, individual skills), social (convention and customs, gender roles, power relations, etc.) and

\footnotetext{
${ }^{5}$ Some expressions of Salvadoran heads of household surveyed by UTEC (2003) reflect this feeling of being incapable to change the current situation or the need to justify it. The phrase "Ser pobre es lo último de la vida, ya que cada día uno piensa qué va a hacer sin dinero" (ibid) expresses the fact that monetary concerns become the priority in life and this stressful situation indicates that the person fell off to the lowest possible position.

${ }^{6}$ Observing an abstract hypothetical situation is rather difficult. Once individuals make a decision (choose a functioning, which we can observe), a new set of capabilities is available. Even though we were able to observe the capabilities set, there would be doubt whether this was the initial and/or the final capability set.
} 
environmental (climatic circumstances, presence of infectious diseases in the region, pollution, infrastructure, public policies, institutional arrangements, etc.). For example, a family living in a house close by to a river does not exhibit the same level of achievement than others living some miles further away have (especially in rainy season when the water level of the river grows and endanger the houses foundations), even if both families have identical houses otherwise. Hence, the relation between income and capabilities varies between communities and between people in the same community.

\section{The transformation process from resources to functionings}

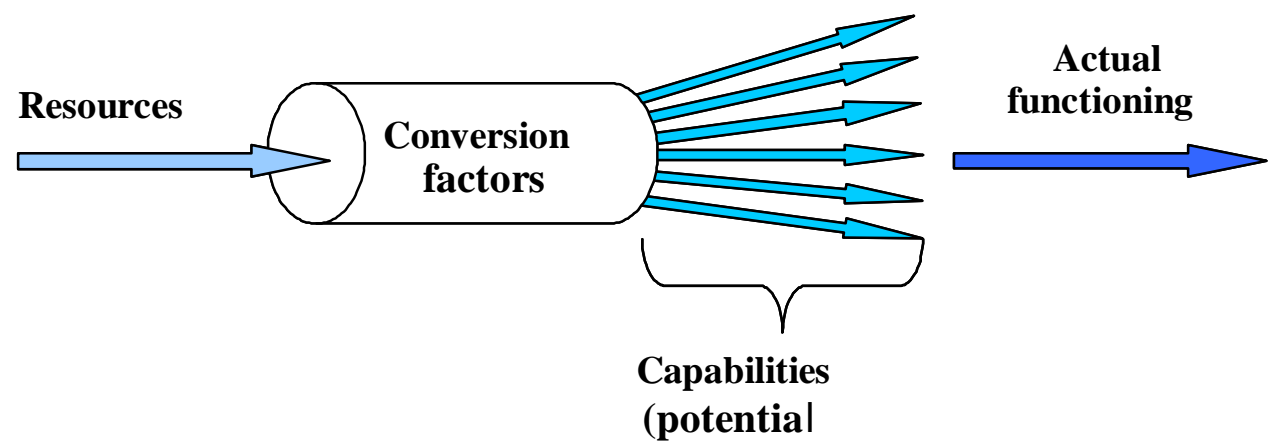

functionings)

Figure 2 The transformation process from resources to functionings.

Thus it is not enough to evaluate wellbeing by using a monetary measure. A monetary measure is instrumentally rather than intrinsically valuable. A person's wellbeing may be different if evaluated from different dimensions. ${ }^{7}$ For instance, if someone had an income above the official poverty line, he or she might still live in inadequate housing or might be socially excluded due to low education.

\footnotetext{
${ }^{7}$ Laderchi, Saith and Stewart (2003) present information from a study of India and Peru based on national data sets and micro-surveys. This study found that "significantly different people were identified as poor in the two countries according to whether the monetary, capability or participatory approach was adopted" (ibid: 32). Monetary poverty was based on the national poverty lines, while capability poverty included education and health achievements.
} 
Hence, our aim is to identify some centrally important functionings in the Salvadoran reality. We consider that it is important to analyse these aspects separately and we identify indicators that refer to 1) functionings and 2) resources, which are, as just explained, not converted equally into functionings. The next section discusses these issues.

\subsection{The selection of our functionings list and indicators}

We use the criteria suggested by Robeyns (2003) to select a list of capabilities: Explicit formulation, methodological justification, sensitivity to context, different levels of generality, exhaustion and non-reduction. Our list is the result of the comparison of different lists starting with Nussbaum's list of central human capabilities and other discussed by Alkire (2002). After identifying our list of dimensions we will justify our choice, while also discussing the limitations of the dimensions in the context of the EHPM El Salvador household survey. An overview of our dimensions, the ideal indicators and the feasible indicators used is given in Appendix 1.

\section{Table 2 Our list of functionings}

\begin{tabular}{|cl|}
\hline 1. & Life and physical health \\
1.1 & Life and reproduction \\
1.2 & Physical health \\
\hline 2. & Security, shelter and environment \\
2.1 & Physical Security \\
2.2 & Shelter and environment \\
\hline 3. & Education and knowledge \\
3.1 & Education \\
3.2 & Knowledge and practical reason \\
\hline
\end{tabular}

\begin{tabular}{|cl|}
\hline 4. & Mental wellbeing \\
4.1 & Mental health \\
4.2 & Emotions \\
4.3 & Economic Security \\
4.4 & Leisure activities \\
\hline 5. & Social relations \\
5.1 & Friendship \\
5.2 & Community opportunities \\
\hline 6. & Freedom of choice and action \\
6.1 & Political freedom \\
6.2 & Self-realisation \\
6.3 & Other \\
\hline
\end{tabular}

The first category "Life and physical health" is repeated in almost all other capability lists (e.g. "Bodily wellbeing" in Narayan et al. (2000a)). It refers to basic needs (i.e. bare survival) that are an imperative factor of wellbeing. Category 1.1 "Life and reproduction" refers to being able to lead a long life. In the case of women, it includes having access to 
safe birth control and child-bearing. Ideal indicators to measure this capability are life expectancy at birth, mortality rates of women at childbirth, etc. In our dataset we have no indicators on this category, as those indicators are usually measured on a macro-level level.

Category 1.2 "Physical health" is about nutrition and morbidity. A good indicator would be the nourishment level. We were able to find some resource indicators in our dataset, for example whether any household members attended a health check-up to explain the opportunity of being healthy. We also created an index of health ${ }^{8}$ which gives the health status for each household member ranging from healthy to fatally sick. This indicator thus represents the functioning of being able to live a healthy life. It should be noted that this variable refers to self-reported health, it is thus measured subjectively.

Dimension 2 "Security, shelter and the environment" is also present in other lists (e.g. "Protective housing" in Doyal and Gough (1991)). Category 2.1 "Physical security" is about being able to be safe both inside the house (e.g. from domestic violence) and outside (e.g. from robbery). Organised crime and gang delinquency remains a serious problem for most of the Salvadoran population. An ideal indicator to measure this dimension is a public opinion poll Latinbarómetro, asking how many times a person was assaulted during the previous year and how safe they felt. There is no direct question on security in the survey, but we have a resource indicator for safety, namely phone possession which can suggest whether one can call for help in the case of an emergency.

Category 2.2 "Shelter and environment" refers to being able to live in adequate housing in a non-polluted neighbourhood, in harmony with the environment. At this stage it has to be pointed out that not all aspects of this dimension represent a capability. "Decent shelter" is a resource to achieve a capability (e.g. safety from a hurricane). There are

\footnotetext{
${ }^{8}$ The interviewees were asked if they had a particular symptom/ disease/ injury during the past month. We grouped theses diseases into "light disease", e.g. a headache, "chronic disease", e.g. Diabetes, "serious disease", e.g. Malaria and "fatal disease", e.g. cancer. We then created a health index which also contains the option "healthy".
} 
various indicators to measure the resources for housing, for example measuring a crowding index using equivalent adults, asking about sanitation and cooking facilities etc. The environmental aspect of resources is more difficult to measure. One way could be the question of whether the interviewee is aware of sustainable agricultural practices. One selected resource indicators is solid waste disposal. It indicates how the households dispose of their waste, one possible answer is "burning it" which is obviously very harmful for the environment.

We consider dimension 3 "Education and knowledge" a very important one. Being educated and knowledgeable makes a difference in shaping opportunities in life (ranging from a better job to being able to understand medical prescriptions). This dimension is not explicitly mentioned in most other capability lists, but for example Nussbaum's "Practical reason" (2000) includes it. A functioning indicator for category 3.1 "Education" is the literacy rate, whereas a resource indicator is whether there is a school in nearby proximity. We have several feasible indicators, e.g. the last level of education achieved and the primary and secondary school enrolment rate for children. An indicator for category 3.2 "Knowledge and practical reason" could be how many books the person read during the last year. For this dimension we only have a weak proxy, namely ownership of radio. We assume that if this is the case, the owner is at least somewhat informed on the news.

A dimension like "Mental wellbeing" is present on most other lists (e.g. "Psychological well-being" by Narayan et al. (2000a)), thus recognising that it is not just physical health that contributes to a valuable life. We include four sub-categories that contribute to mental wellbeing. Category 4.1 "Mental health" refers to being free from specific mental illnesses, e.g. depression. A psychological assessment could indicate whether this is the case. We have no functioning indicator for mental health, as the list of diseases used for the health index did not include any mental illnesses. We have a resource indicator however: We created a variable of whether the individual goes to school, works or stays at home by choice. We assume that when someone has something to do, he or she feels 
happier. We thus assume that a satisfying job has an intrinsic value. We also consider unemployed or disabled who cannot work as unhappy and more prone to mental illness. Ideally we would also like to include an indicator on trauma from the civil war, but this is not available.

Category 4.2 "Emotions" is more abstract. It comes from Nussbaum's list and it means "being able to have attachment to things and people outside ourselves" (Nussbaum, 2000, p. 79). Also important for emotions are self-esteem and respect for others. It is about being able to be confident and not discriminated against. A functioning indicator would be the question of whether the interviewee feels respected. We use a resource indicator from our dataset which is whether the individual owns his or her house (we thus assume that in El Salvador house owners are respected ${ }^{9}$ ), which is a variable in our dataset. We think that family situation may explain "emotions" (e.g. divorce/ death of a partner generally makes people feel unhappy). We also include a proxy variable for children, namely "Why do you not study". We consider four to eighteen year olds who do not study as unhappy (i.e. they have a restricted capability set), except if their reply is due to "age", "having finished" or "not being interested" (cultural issues apply here).

Category 4.3 "Economic security" is about having a steady job and income. Lack of economic security (unemployment, low wages, etc.) is an important reason for migration. A resource indicator could be access to social protection and more importantly, a permanent job. Two functionings indicators in our dataset are whether the working members of the household (older than twelve) are in independent/dependant employment and whether they have a job contract. Finally, category 4.4 "Leisure activities" refers to having access to an affordable cinema or sports facility in the neighbourhood, for instance. There is no variable in our dataset to measure this.

9 Most Salvadorans do not have the official property titles however, but since this is the case for most of them we assume that it does not affect mutual respect. 
Dimension 5 "Social relations" is also found on many lists. It ranges from personal friendship to activities and infrastructure on a community level. Social networks and families are the main insurance mechanism, in a country, where the welfare state is small. This dimension is difficult to measure objectively, ideal indicators are direct questions like, "Do you receive support from others?" Unfortunately the household survey contained no direct variables that could be used. We created one functioning indicator for category 5.1 "Friendship", namely "Social activity" which explains whether the individual goes to school or work, where he or she has at least the possibility of creating and maintaining social contacts. A resource indicator is whether the household owns a phone; this indicates whether friendship can be maintained without daily contacts as well. We have no indicators on category 5.2 "Community opportunities".

The last dimension "Freedom of choice and action" (like in Narayan (2000a)) is fundamental because, as discussed before in section 2.1, not having this freedom might restrict the entire capability set extensively. The categories we consider important are political expression (i.e. freedom of speech, real democracy), self-realisation and others, for example mobility. We have no indicator for category 6.1 "Political freedom". Category 6.2 "Self realisation" refers to being able to choose the education, job, lifestyle and religion which make one's life fulfilled. A functioning indicator could be whether someone is satisfied with what he or she does. ${ }^{10}$ Mobility, part of the category 6.3 "Other" is especially vital in the Salvadoran context, as migration is sometimes the only way to make a living. Two resources indicators could be: Whether someone in the household travelled abroad during the past six months and whether the household owns a car.

\footnotetext{
${ }^{10}$ Nevertheless people living in long-term poverty might have adjusted their expectations to their harsh reality in order to go on with their lives. Therefore, it is useful to include objective descriptive indicators as well as subjective evaluative indicators.
} 


\subsection{Fuzzy Sets theory}

We follow Chiappero Martinetti (2000) and Quizilbash (2002) in their aim to assess the multidimensional concept of wellbeing by using the Fuzzy Sets theory.

Wellbeing and inequality, according to Sen, "are broad and partly opaque concepts" (1992, p. 48). Fuzzy Sets theory (first introduced by Zadeh (1965)) is ideal for analysing inexact, broad, ambiguous and fuzzy concepts like wellbeing, as Fuzzy Sets allow for gradual transition from one state to another ("the degree of membership") and permits the use of indicators of any kind (binomial/ qualitative/ quantitative/ subjective/ objective). Fuzzy Sets theory thus classifies individuals on a spectrum from poor to non-poor from sick to healthy etc. The statements made are fuzzy instead of clear, but at the same time much more precise because no arbitrary cut-off levels are chosen.

The Fuzzy Sets methodology uses a membership function (or characteristic function) which varies between 0 and 1 to denote the degree of membership:

When we have a set $X$ (for example all people of El Salvador) and a fuzzy sub-set $A$ (for example all healthy Salvadorans), we can say the following about membership:

$0 \leq \mu_{A}(x) \leq 1$

where $\mu_{A}$ is the membership function of individual $x$ in the subset $A$

$\mu_{A}(x)=0$ if individual $\mathrm{x}$ does not belong to $\mathrm{A}$ (for example he or she is fatally sick)

$\mu_{A}(x)=1$ if individual $\mathrm{x}$ fully belongs to $\mathrm{A}$ (for example he or she is completely healthy)

$0<\mu_{A}(x)<1$ if individual $\mathrm{x}$ partly belongs to A (for example he or she has a cold)

Larger membership values thus represent a higher degree of membership.

The specification of these membership functions is the biggest challenge in the Fuzzy Sets methodology. Lelli (2001) classifies all membership functions into two approaches: 
The first approach is "distance-based". In this case the membership value is based on the distance to the ideal element. The distance can be calculated in various ways. The basic membership function is a linear function. The highest achievement is assigned the value one $\left(x_{\max }\right)$ and the lowest achievement the value zero $\left(x_{\min }\right)$. The intermediate values are determined by the following formula:

$\mu_{A}(x)=\frac{x-x_{\min }}{x_{\max }-x_{\min }}$

This membership function is well-suited for equi-distributed modalities along an ordinal scale. It is easy to specify, interpret and visualise (Lelli, 2001). On the other hand, this specification is not always appropriate, for example when a lower/higher value than the highest/lowest is still considered to have full/ no membership. ${ }^{11}$ In that case it is more suitable to use a trapezoidal function. It is specified in the following way:

$$
\begin{aligned}
& \mu_{A}(x)=1 \text { if } x \geq z \\
& \mu_{A}(x)=0 \text { if } x \leq y \\
& \mu_{A}(x)=\frac{x-y}{z-y} \text { if } y \leq x \leq z
\end{aligned}
$$

Of course this threshold is conditional on subjective assessments by the researcher.

There are more options, for example the sigmoid or logistic function, which is suitable for quantitative/qualitative variables with modalities that are not equi-distributed. This method is not used in this paper however.

The second approach to membership function is "frequency-based", which means that membership is derived from on the relative frequency distribution of the possible outcomes. Cheli and Lemmi (1995) developed this approach and the membership equation can be simplified to the following formula:

\footnotetext{
${ }^{11}$ For example the variable "cooking facilities" has four possible replies: "Electricity", "Gas", "Wood" and "None". We consider electricity (only $0.84 \%$ of Salvadorans have this facility for cooking) and gas to be equally good, so we decided that they both have full membership.
} 
$\mu\left(x_{k}\right)=\frac{F\left(x_{k}\right)-F\left(x_{\min }\right)}{1-F\left(x_{\min }\right)}$

where $\mu_{A}$ is the degree of membership of variable $\mathrm{x}$ which has the $\mathrm{k}$-th place in the sampling distribution arranged in an increasing order and $\mathrm{F}$ is the cumulative frequency.

This approach avoids an a-priori and arbitrary choice of membership function and the membership values follow from the sampling distribution, i.e. there is empirical, objective evidence for them. This specification also has a theoretical explanation in some contexts. Poverty and deprivation are considered socially relative concepts and this is exactly how it is measured with the totally fuzzy and relative approach. In other contexts it is not suitable however. For example in terms of nutrition we are interested in absolute levels: If everybody else is starving too, we still want to classify all of them as undernourished.

Appendix 2 lists the choice of membership functions and specifications for each of our variables.

After each achievement of each individual has been translated into an indication of wellbeing for that indicator, we want to translate two or more indicators into an aggregated index of wellbeing. There are several methods of doing this. The first aggregation method is called "Fuzzy intersection" and it depends on the satisfaction of all conditions. It is thus an index of deprivation. The different variants and their advantages are described in the table below. The second aggregation method is called "Fuzzy union" and it depends on the satisfaction of at least one of the elements. The resulting index shows the best performance. The variants are again described in the table below for the case of aggregation of two indicators. 
Table 3 The different variants of the fuzzy intersection and fuzzy union method

\begin{tabular}{|c|c|c|}
\hline Fuzzy intersection & Fuzzy union & Advantage \\
\hline $\begin{array}{c}\text { Standard variant: } \\
\operatorname{Min}(a, b) \\
\text { Minimum degree of } \\
\text { membership (take lowest } \\
\text { membership of both conditions) }\end{array}$ & $\begin{array}{c}\text { Standard variant: } \\
\operatorname{Max}(a, b) \\
\text { Take highest degree of } \\
\text { membership }\end{array}$ & $\begin{array}{l}\text { Useful if there is positive } \\
\text { correlation between the indicators. }\end{array}$ \\
\hline $\begin{array}{l}\text { Weak intersection: } \\
\qquad a^{* b} \\
\text { Take product of both } \\
\text { memberships } \\
\end{array}$ & $\begin{array}{c}\text { Weak union: } \\
(a+b)-\left(a^{*} b\right) \\
\text { Add memberships and subtract } \\
\text { weak intersection } \\
\end{array}$ & $\begin{array}{l}\text { Allows compensation for } \\
\text { independent indicators, as all } \\
\text { indicators are considered. }\end{array}$ \\
\hline $\begin{array}{c}\text { Bounded difference: } \\
\operatorname{Max}((a+b)-1,0) \\
\text { Add membership functions and } \\
\text { subtract } 1 ; \\
\text { it is } 0 \text { if the result is smaller } \\
\text { than } 0\end{array}$ & $\begin{array}{c}\text { Bounded sum: } \\
\text { Min }((a+b), 1) \\
\text { Add memberships; if higher than } \\
\text { 1, make the result } 1\end{array}$ & $\begin{array}{l}\text { Useful if there is negative } \\
\text { correlation between indicators, but } \\
\text { it tends towards extreme values. }\end{array}$ \\
\hline
\end{tabular}

In our analysis we cannot aggregate all the indicators to an overall index of wellbeing for the whole population, as some of our indicators are only measured for certain subgroups, for example we only use the health check-up variable for children. We are also unable to calculate an overall index of wellbeing for the subgroup (i.e. households with children under the age of eighteen), because many missing values in some of the variables (namely contract, health check) results in an overall number of observations of around 1000 , which is not enough to draw conclusions on. Instead we compare the different indicators and dimensions. This is also more relevant when analysing multi-dimensional wellbeing. We use fuzzy unions and fuzzy intersections to aggregate the indicators into a dimension, for details see Appendix 3.

\section{Data analysis}

In theory we want to calculate wellbeing on an individual level. Once again, due to data restrictions this is not possible. Many of our indicators of wellbeing (e.g. type of house, and more importantly remittances) are only calculated on a household level. Since we do not know the distribution within a household, we decide to focus on a comparison between individuals in households. 
This means that we analyse the wellbeing at an individual level but considering the functionings of his or her household for each individual. We consequently augment some of the indicators to be used on the household level, for example education on a household level is taken to be the education level of the household head. Therefore, if the head of the household completed primary education, each individual of that specific household will have that achievement for the education level. In the same way, if one of the children in a specific household does not have a health check-up, every member of this household regardless the age will have a zero achievement in this variable.

In this section we discuss the functionings for the sampled population as a whole, different groups in the population and different remittances groups for the year $2003 .{ }^{12}$ We also compare out results from a multidimensional perspective with the traditional monetary approach. The analysis will not include dimension 6 as we do not have relevant enough indicators from the questionnaire.

\subsection{Wellbeing evaluation of sample population}

Appendix 4 lists the membership degrees of our sample population for the different indicators and dimensions. In the first dimension "Life and physical health" individuals in households perform badly on attending health checks (85.06 percent of individuals achieve less than 0.1 for this indicator), having health insurance coverage (the average membership value is less than 0.1) and in travelling quickly to the health centre (almost 50 percent of the population achieves less than 0.1 ). The individuals achieve fairly high on getting decent health care ( 0.44 on average) and very well on the health indicator (86.68 percent of individuals achieve between 0.91-1). The latter indicator is selfreported and must be taken with caution. For instance, only 15.36 percent of individuals reported having had a symptom, disease or injury in the previous month (50.76 percent of them, had flu or cold) and there is not a very significant correlation between being sick

\footnotetext{
${ }^{12}$ We also worked with the years 2001 and 2002, but the results are very similar, which shows that the methods used are quite robust. If there are striking differences between the years they will be named in the text.
} 
and age (0.0448). Since we are measuring best performance for the first dimension, our sample households do very well on this dimension with an average achievement of 0.99 . This number is only for households with children, since the health check indicator only concerns children.

Individuals in households achieve high wellbeing in the second dimension, "Security, shelter and the environment". For example 92.80 percent of individuals achieve a membership value between 0.91-1 for housing (most Salvadorans live in free-standing houses) and the average membership value for lighting is 0.86 . Households tend to live in crowded conditions, resulting in a lower achievement for rooms/ household member (an average membership value of 0.57) and many households do not dispose of waste properly (e.g. by burning it), for example 54.98 percent of individuals have a membership value less than 0.2. Overall achievement on this dimension is fairly low (with an average membership of 0.26), as we are measuring deprivation by using the fuzzy intersection standard variant.

For the third dimension "Education and knowledge" households are far from having universal literacy (average membership is 0.76) but they achieve fairly well on having a school close-by (85.65 percent of individuals achieve a membership value higher than 0.5). Households also perform quite well on the education level indicator (average achievement of 0.64). It seems that many households neglect to enrol all children at school, which results in a very low achievement for the enrolment rate $(68.64$ percent of households have a membership of less than 0.1). Wellbeing for the whole dimension (again only for households with children) has an average of 0.54 , however, with 44.12 percent of households with an overall achievement of less than 0.1. Note that in other years overall wellbeing for this dimension is somewhat higher, for example 0.61 in 2001.

The fourth dimension is "Mental Wellbeing". High membership is achieved in mental health, measured by the indicator "meaningful" activity, which has an average membership of 0.86. Achievement on the emotion indicators house ownership and family 
status is passable (average membership values of 0.77 and 0.66 respectively), whereas wellbeing measured by the emotions indicator why not studying is very low (87.16 percent of households achieve a membership value of less than 0.1). Individuals perform fairly well on the economic security indicator employment type (average membership of $0.69)$, but perform very badly on the other indicator, contract (77.44 percent of individuals achieve less than 0.1). Overall mental wellbeing achievement, aggregated with a standard variant intersection is, as expected, low with an average membership of 0.2. It is necessary to recall that this is a proxy variable to measure how well people feel about their life and others.

The fifth dimension "Social relations" consists of two indicators, phone possession (where the wellbeing level achieved is passable) and social activity. Individuals achieve very low wellbeing for social activity, 88.15 percent of individuals have a membership value less than 0.1 . This means, for example, that some household do not send their children to school, which was also shown by low achievement on the enrolment variable. Overall achievement for this dimension is tolerable (at an average membership of 0.49) due to fairly good achievement on the phone variable. Again, this result must be taken with caution as we used proxy variables.

The graph below gives an overview of the distribution of achievements of individuals in households for the dimensions discussed. 


\section{Distribution of achievements for the different dimensions}
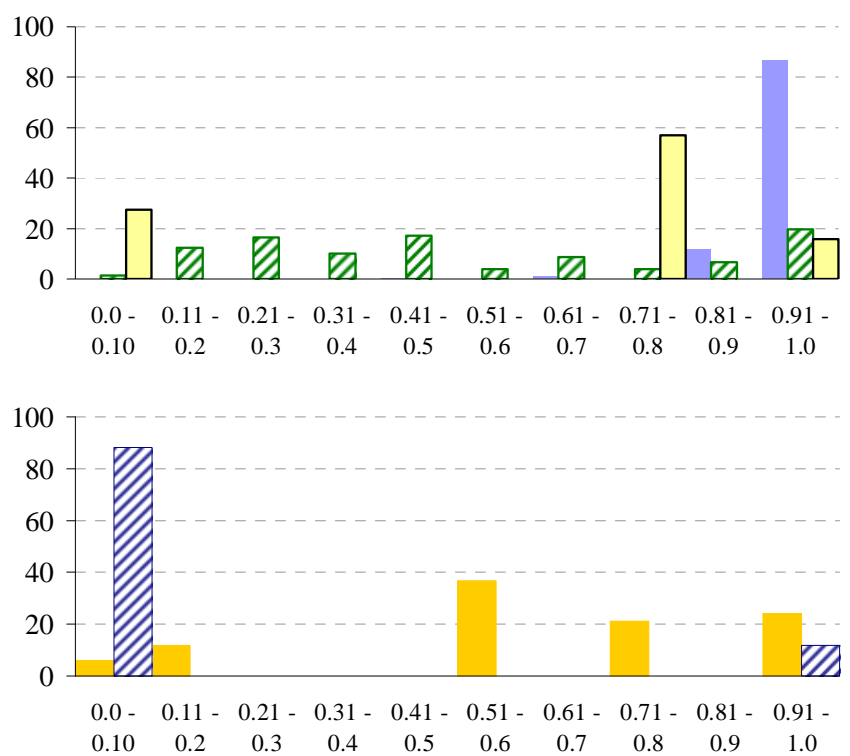

Dimension 1

$\square$ Dimension 2

$\square$ Dimension 3

Dimension 4

Dimension 5
Dimension 1:

Life and physical health

Dimension 2:

Security, shelter and the environment Dimension 3:

Education and knowledge

Dimension 4:

Mental wellbeing

Dimension 5:

Social relations

Figure 3 Distribution of achievements for the different dimensions. Source: Own calculations based on EHPM.

In conclusion, Salvadorans in the sample show a good performance on health. At a first sight, achievements in education and social relations could appear acceptable ( 0.54 and 0.49, respectively, on average) but the membership distributions are quite unequal. Performance in security, shelter and environment is unsatisfactory, while no conclusive statement can be made regarding the low achievements in mental wellbeing because of the way the variables were constructed. 


\subsection{Wellbeing evaluation of certain groups}

Appendix 5 lists the average membership degrees for certain groups, namely urban/ rural, region, household size, gender of the household head and age category of the household head. As expected, the urban group performs much better on all wellbeing dimensions, for example individuals in urban households achieve a membership value of 0.31 for dimension 2 "Shelter" whereas those in rural households only achieve 0.044. Urban households also perform much better on most indicators, for example their individuals have much higher achievement on housing amenities and infrastructure, such as lighting (membership value average of 0.95 vs. 0.75 ), safer water access, better cooking facilities and especially waste disposal (membership value average of 0.75 vs. 0.2 ). Individuals in urban households also achieve higher wellbeing on education, literacy and school enrolment. Individuals in rural households also have lower wellbeing on the social activity indicator; this might be because they place high emphasis on strong family ties and do not consider it necessary to seek social relations outside the family. The only indicators where rural households show better achievement are family status (not surprising), house ownership and why not study, which seemingly contradicts the higher urban enrolment rates. However, this just means that when rural households do not send their children to school, they do so for more legitimate reasons, for example age, related to the fact that there is not secondary education in most of rural locations.

Individuals living in the San Salvador area have the highest wellbeing. They have the highest membership in all dimensions, for example in the second dimension households in the San Salvador region achieve a membership of 0.43, whereas Central 2's household only obtain a membership of 0.1 . The second-best performing region is Central 1, followed by the Western and Eastern region and with Central 2 being the worst performing region. Individuals in the San Salvador region achieve higher memberships on almost all indicators, especially in terms of housing and education (for example a membership of 0.89 in waste disposal is achieved compared to 0.37 of Central 2). This is 
clearly because it is the capital city area and is confirmed by higher urban wellbeing as described in the previous paragraph.

Individuals in medium-sized household achieve higher wellbeing in most dimensions and indicators than those in small households and much more than those in large households. Small households perform well at attending health checks and school enrolment (for example a membership value of 0.43 for health checks compared to the value of 0.15 for medium-sized households), obtaining insurance and of course rooms/ household member (here small households have an average membership of 0.7, medium-sized households have a membership of 0.56 and large households have a membership of 0.35). Mediumsized households perform very well in the second dimension, security, shelter and environment, possibly due to inter-household economies of scale. They also perform slightly better than small households in type of employment and having a contract, maybe because the small household group contains more single parents. This is also confirmed by the worst performance on family status of small households. Large household perform the best on house ownership (a membership of 0.83 compared to 0.74 of medium-sized households and 0.66 of small households).

Male-headed households perform better at all dimensions than female-headed households except for the security, shelter and environment dimension and social relations dimension. This conforms with traditional gender roles. Some notable male-biased differences are the health check and health differences, for example male-headed households have an average membership of 0.97 for health and women of 0.96 (in 2001 the difference is even 0.3). This difference should not be disregarded considering that all groups so far performed very well on the health dimension. Male-headed households also perform somewhat better in terms of the important indicators of employment, contract, literacy and education level (male-headed households have a membership of 0.6 and female-headed households of 0.5 for this indicator). Therefore there would be a slight but significant gender imbalance in El Salvador. 
There is no age category that performs best in all dimensions and indicators, but individuals in households headed by middle-aged (ages 26-55) perform well, followed by those in households around retirement age (ages 56-70). Individuals in households with young household heads (15-25) achieved the next-highest level of wellbeing and those in households headed by old household heads (older than 70) perform the worst. Youngheaded household perform much better at literacy (membership values are 0.84 for the youngest, 0.79 for those in the 26-55 category, 0.67 for those in the 56-70 category, and 0.58 for those with a household head older than 70), education level, family status and social relations. Individuals in households headed by middle age to retirement achieve higher wellbeing for all housing indicators and also employment indicators. While there is not a completely clear picture on achievement versus the age category of the household heads, it should be noted that individuals in households headed by elderly generally achieve the lowest wellbeing.

A wellbeing analysis by different groups revealed that urban individuals, living in the San Salvador area, in medium-sized, male and middle-aged headed households achieve the highest wellbeing. Rural individuals living in large households in the Central 2 region and headed by elderly females, achieve the lowest wellbeing.

\subsection{Migration and wellbeing}

In the sample almost one in five households have a family member abroad, the percentage of urban households is slightly higher at 18.23 percent. Out of those households having a member abroad almost 58.30 percent have one member and 41.70 percent have more than one member.

The percentage of urban households receiving remittances is also higher at 22.86 percent, compared to 20.76 percent of rural households. This means that some households that do not have a family member abroad nevertheless receive remittances, e.g. from a friend or extended family member. Households receiving remittances mostly receive them in cash, 
followed by in cash and in kind, both in rural and urban households. Less than one percent of households receive only in kind remittances. Those households receiving remittances get them fairly frequently. 72.70 percent of households receive remittances every two weeks to monthly. Very few households receive remittances of more than 500 dollars when they receive remittances. 51.56 percent of households receive less than or equal to one hundred dollars and 29.92 percent of households receive 101-250 dollars. Not even one percent of households receive more than one thousand dollars.

It is also interesting to look at what the remittances are spent on 54.98 percent of households spend a positive amount, less than or equal to one hundred dollars, of money received from remittances on consumption. 31.19 percent of households spend between 101-250 dollars and 12.56 percent of households spend between 251-500 dollar. This distribution of spending on consumption mirrors the distribution of amounts received. This is confirmed by the fact that very little of the remittances money is spent on other things, 98.85 percent of households spend nothing on housing, 99.47 percent of households spend nothing on their business, 92.00 percent of households spend nothing on education (8.00 percent spend less than or equal to 100 dollars) and 96.45 percent of households spend nothing on health (5.28 percent spend less than or equal to 100 dollars).

The above statistics showed that in the sample about one in five households have a member abroad and receive remittances. These households receive remittances frequently, but at fairly small amounts. Almost all the money received is spent on consumption. We now analyse whether these remittances nevertheless affect household wellbeing.

Appendix 6 lists the average membership degrees for groups with a different migration and remittances status, namely if the household has a member abroad, if they receive remittances and the amount and frequency of remittances. Having a family member abroad gives a household higher wellbeing in all dimensions except for health. In terms of indicators, households with a member abroad perform much better in all housing 
indicators (having a membership value of 0.92 compared to 0.83 for lighting for example). These households also perform better at school enrolment and house ownership, but have a lower achievement on the literacy, education and family status indicators. No conclusions on causality can be drawn here, but it is possible that the more poorly educated households are more likely to send family members abroad.

The next comparison, if a household received remittances and of what kind, revealed some interesting results. Individuals in households receiving in-kind remittances showed the highest wellbeing for the different dimensions, followed closely by receiving both inkind and cash remittances. Households receiving no remittances had the lowest wellbeing except for the health and education dimension (the order is somewhat different for the year 2002, but no-remittances households are nevertheless the worst performers). Households receiving in-kind remittances show a higher wellbeing, with a especially large difference for social relations (a membership of 0.65 for households with in-kind remittances compared to 0.55 for households with cash remittances). It is possible that these households depend less on remittances for subsistence as they have other activities. In addition, owning the foreign product could provide them respect from others.

With regard to the different indicators individuals in households receiving remittances do best for almost all indicators, but especially for the security, shelter and environment indicators, for example individuals in households receiving both kinds of remittances have a membership value for phone possession of 0.62 , those in households with cash remittances have a value of 0.51 , those in households receiving in-kind remittances have a value of 0.46 and others in households that get no remittances have a membership of 0.26. Individuals in household receiving cash remittances have the worst performance on education and literacy. This corresponds with the statistics quoted earlier, which showed that most of the remittances received are spent on consumption.

There is no clear picture on which frequency of remittances affects wellbeing the most. Individuals in households receiving remittances every two weeks to monthly (the second- 
most frequent option) show the best achievement, but not consistently on all dimensions. Individuals in households receiving remittances the most frequently (more often than every two weeks) show the worst performance on the education dimension. The same ambiguous conclusions hold for the individual indicators. More frequent payments seem to influence a household's wellbeing on some of the housing indicators positively, while households receiving only half-yearly to yearly remittance payments have a higher average membership value of 0.61 for the employment indicator, compared to a membership of 0.51 for households receiving remittances the most frequently. It should be noted here that the results for 2001 and 2002 differ somewhat for some indicators and dimensions, both in the level of membership value and relative ordering between types of households. This means that the conclusions from this analysis are not completely robust.

The next analysis considers the effect of the amount of remittances on wellbeing. As we noted earlier, remittances of more than one thousand dollars do not occur frequently. This means that the analysis with respect to high amounts of remittances is not very robust, for example the membership value for dimension 2 for households receiving \$2501 and more is 0.91 in the year 2003 and 0.18 in the year 2001. The membership values for smaller amounts are consistent between the years. Due to the high fluctuations, wellbeing for amounts higher than one thousand dollars will not be considered. For the smaller amounts of remittances, wellbeing on all dimensions is greater, the higher the amount of remittances received. For example for dimension 3, households receiving \$501-1000 have a membership value of 0.6 , households in the remittances category below have a membership of 0.54 , households receiving $\$ 101-250$ of remittances have an average membership of 0.51 and households receiving less than one hundred dollars have a membership value of 0.47 . Households receiving \$501-1000 of remittances generally have higher wellbeing for the individual indicators as well, especially in the housing and education dimension. This is not so much the case for health (as was shown earlier less than three percent of households receiving remittances spent any of it on health), and the households receiving the least remittances have the highest wellbeing for the indicator 
activity. This could mean that those households still need to earn money by having a job and therefore have complete membership for the indicator activity.

In the previous paragraph, we showed that individuals in households receiving higher amounts of remittances have greater wellbeing in the security, shelter and environment dimension. The next analysis will consider whether this is also the case for remittances specifically spent on housing. This analysis again suffers from low observations, therefore the results should be interpreted with care. The highest remittance category will be ignored due to intolerable low observations. It is clear that households receiving no remittances show the lowest wellbeing for several housing indicators, e.g. toilet, as well as for the whole dimension 2 (see Appendix 6). Between the other remittances categories the ordering is less clear, households receiving $\$ 251-500$ of remittances show the greatest wellbeing for some indicators and dimension 2 , but not always so.

The final analysis looks at whether households spending remittances on education have higher wellbeing (see Appendix 6 for the tables). As before, low observations mean that the results are not overly robust and the highest two remittances categories will be ignored. Households spending \$251-500 on remittances have a higher wellbeing for dimension 3 (of 0.65) compared to households that spend no remittances on education (their membership is 0.5). But households receiving $\$ 100$ or less have higher wellbeing (0.49) than households receiving \$101-250 (who have a membership value of 0.37). For the different indicators, households receiving no remittances show the lowest wellbeing (except for school travel) and households receiving the highest amounts of remittances generally show the highest wellbeing. Nevertheless there are no huge differences in wellbeing between households spending no, low and great remittances on education.

The analysis by migration and remittances status showed that households who send a family member abroad have higher wellbeing. This is also the case, when they receive remittances, especially if these are in the form of in-kind or in-kind and cash benefits. Receiving remittances fairly frequently (approximately monthly) also seems to result in 
higher wellbeing. The greater the amount of remittances received by households, the more positive is their wellbeing performance. Household spending remittances specifically on housing, show higher wellbeing for several housing indicators and dimension 2 and wellbeing increases, the higher the amount spent on the dimension. Households that spend remittances specifically on education have higher wellbeing than households who do not, but the difference is not very large.

\subsection{Monetary Poverty vs. Multi-dimensional Wellbeing}

In section 2 we argued that a multi-dimensional analysis gives a better picture of wellbeing than a monetary-based analysis. We use the official absolute poverty line to compare wellbeing of poor and non-poor groups, according to the five dimensions analysed in previous sections. We use expenditures as the monetary indicator. ${ }^{13}$

We measure poverty using the head count ratio (i.e. the number of households that have monthly household expenditures lower than the official absolute poverty line). In the year 2003, 18.46 percent of households in our sample lived below the poverty line. Poverty is much more common amongst households that do not receive remittances. According to SIEMMES-OIM (2005) only 15.3 percent of households in the whole country that receive remittances are poor, whereas 84.7 percent of no-remittance receiving households are poor. This difference is even more pronounced in rural areas. ${ }^{14}$

\footnotetext{
${ }^{13}$ Our income data file showed some inconsistencies. Nevertheless, using expenditures was not a secondbest choice since expenditures are a better indicator of true purchasing power, as income fluctuates much more in the short-run and expenditures can be smoothened taking future income into account.

${ }^{14}$ Our number of households differs from SIEMMES-OIM's number of households because we only use the number of households for the sample, without expansion to the whole population.
} 
Table 4 Households receiving remittances by monetary poverty (Year 2003)

\begin{tabular}{|l|rrr|rrr|rrr|}
\hline & \multicolumn{3}{|c|}{ Total Country } & \multicolumn{3}{c|}{ Urban Areas } & \multicolumn{3}{c|}{ Rural Areas } \\
& Total & With & Without & Total & With & Without & Total & With & Without \\
\cline { 2 - 10 } & thousands & $\%$ & $\%$ & thousands & $\%$ & $\%$ & thousands & $\%$ & $\%$ \\
\hline Total & $\mathbf{1 , 5 9 0}$ & $\mathbf{2 1 . 4}$ & $\mathbf{7 8 . 6}$ & $\mathbf{9 9 0}$ & $\mathbf{2 1 . 0}$ & $\mathbf{7 9 . 0}$ & $\mathbf{6 0 0}$ & $\mathbf{2 2 . 2}$ & $\mathbf{7 7 . 8}$ \\
Poor & 574 & 15.3 & 84.7 & 297 & 16.0 & 84.0 & 277 & 14.7 & 85.3 \\
Non-poor & 1,016 & 24.9 & 75.1 & 693 & 23.2 & 76.8 & 323 & 28.6 & 71.4 \\
\hline
\end{tabular}

Source: SIEMMES-OIM, 2005.

When looking at individuals in households in our dataset we also find that more non-poor than poor receive remittances. We cannot draw any conclusions on causality. It could be that the extreme poor cannot afford to migrate or that the non-poor are better off due to remittances. There is some evidence for the latter hypothesis, because those poor that do receive remittances have 10 percent higher expenditures.

Figure 4 shows the average membership values for the five wellbeing dimensions of individuals in poor households, compared to those in non-poor households. Monetary poverty and multi-dimensional wellbeing are consistent with each other, because individuals in poor households show a much lower wellbeing in all dimensions, except for dimension 1, than non-poor households. However, the multidimensional analysis adds another facet: It shows in which areas the less well-off households have higher shortfalls of wellbeing. Poor households show much lower wellbeing compared to non-poor households in the social relation dimension (a shortfall of 0.26), than in the mental wellbeing dimension (a shortfall of 0.11). 


\section{Monetary poverty vs. multi-dimensional wellbeing}

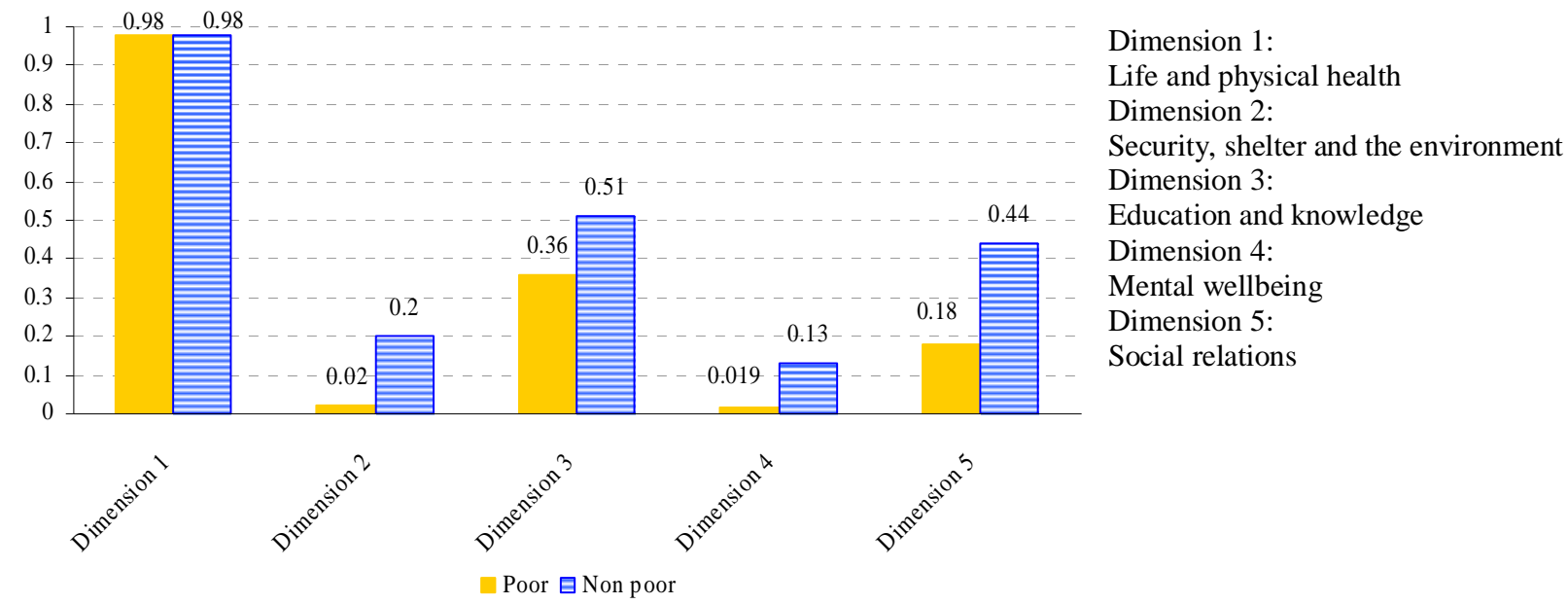

Figure 4 Monetary poverty vs. multi-dimensional wellbeing. Source: Own calculations based on EHPM

Next we show the achievement of individuals in households on two dimensions by poverty and remittances status. The table below outlines the achievement for dimension 2 "Shelter" and dimension 5 "Social relations" by poverty and remittance status. These two dimensions are presented because, as was shown earlier, the remittance status makes a difference to achievement on these dimensions.

\section{Table 5 Average achievement by poverty and remittance status}

Dimension 2 "Shelter"

\begin{tabular}{|c|c|c|}
\hline & Poor & Non-poor \\
\hline Remittances & 0.16 & 0.34 \\
\hline $\begin{array}{c}\text { No } \\
\text { remittances }\end{array}$ & 0.11 & 0.27 \\
\hline
\end{tabular}

Source: Own calculations based on EHPM
Dimension 5 "Social relations"

\begin{tabular}{|l|c|c|}
\hline & Poor & Non-poor \\
\hline Remittances & 0.33 & 0.66 \\
\hline $\begin{array}{l}\text { No } \\
\text { remittances }\end{array}$ & 0.26 & 0.48 \\
\hline
\end{tabular}

As seen earlier, both non-poor and remittances-receiving households achieve higher wellbeing. The tables show that being non-poor and receiving remittances is the combination that achieves the highest wellbeing. 


\section{Conclusions and implications}

The fact that remittances are highly important in the aggregate Salvadoran economy induced us to study their wellbeing effect on a micro-level. Furthermore, because we consider that wellbeing includes aspects beyond monetary indicators, we used the capability approach as departure point. This approach was briefly introduced and the reasons for an evaluation of wellbeing based on functionings (instead of capabilities) were presented. Then, we identified dimensions of life relevant for Salvadoran reality and selected indicators from the EHPM survey.

We were only able to perform a restricted analysis of capabilities due to lack of information in the current set-up of the household survey. However, we presented some ideal indicators. We think that in the future, the EHPM survey should definitely include some more direct indicators on social relations, political freedom and security, only naming some.

We compared the wellbeing of different groups, for example by gender of the household head and migration status of the household. We found that individuals in households living in monetary poverty indeed performed worse than in terms of functionings than the non-poor. However, the multi-dimensional wellbeing method gave us a much wider and useful picture of wellbeing than the traditional monetary poverty approach. It also highlighted the problem areas of different groups in El Salvador.

Our analysis revealed that households in El Salvador have a high achievement in health (keeping in mind the data problems already discussed), unequal education status and satisfactory opportunities for social relations. The sample population also showed some very serious wellbeing shortfalls, namely in regular attendance of health checks for children, being health insured, disposing of waste in a clean manner, enrolling all children at school and having economic security through a job contract. These findings show the relevance of looking at different dimensions independently for different 
population groups in order to identify those who are most deprived in different dimensions (and in which) and who would need immediate support of the government (for instance, in social insurance and employment policies).

There are actions that could be organised at local level. For instance, education campaigns on waste disposal and safe water use to promote health (it was striking that health outcomes were so positive, while there are shortages in water availability and sanitation in general, which made us to doubt the self-reported health status). Most importantly school enrolment should receive some incentives, as this not only negatively influences the education dimension, but also mental wellbeing. If enrolment rates are low now, this will have serious negative consequences for future wellbeing.

The micro level analysis confirms the well-known finding that rural households with elderly and female household heads achieve lower wellbeing. The remittance status of a household also seems to affect wellbeing. Households achieve higher wellbeing if a member is abroad and or if the household is receiving remittances. Households receiving higher and more regular remittances generally also show greater wellbeing. Most remittances seem to be consumed or invested in the house. Households receiving remittances and or spending remittances on education, barely show higher wellbeing on the education dimension than households that do not.

Currently, the Salvadoran government encourages the receipt of remittances, but at the same time it could start promoting investing remittances in education. Macro policies to promote investments in productive sectors would still have low effect, as long as households use migration as a way to improve their consumption (the main use of remittances). Nevertheless, associations of migrants (Home-Town Associations) can make investments of this kind, and hence, should be strengthened and supported.

In terms of future research, it would be useful to group different indicators using factor analysis and compare the results with the dimensions we identified (and the indicators we 
used in each). Furthermore, in terms of individuals in households, some clusters could be identified with the purpose of targeting social protection policies to specific groups. Hence, although we are not able to draw conclusions on causality related to remittances, wellbeing and monetary poverty, we consider that this study is a valid starting point to deepen the use of Fuzzy Sets to assess wellbeing in specific groups. 


\section{References and selected bibliography}

Alkire, S. (2002). Valuing Freedoms: Sen's Capability Approach and Poverty Reduction. Oxford: Oxford University Press.

Andrade-Eekhoff, K. (2003). Myths and Realities: The economic impact of international labour migration in rural El Salvador. Paper presented at the International Migration Conference in the Americas: Emerging Issues Conference, York University, UK.

ASIPES (2002). La migración y su vinculación con las remesas familiares en El Salvador, [Internet]. Available:

http://digestyc.gob.sv/DigestycWeb/Public_MECOVI/La\%20migraci\%F3n\%20y\%20su \%20Vinculaci\%F3n.pdf [2005, 13 April 2005].

Baliamoune, M. (2004). On the Measurement of Human Well-being: Fuzzy Set Theory and Sen's Capability Approach: UNU-Wider Research Paper RP2004/16.

Bandemer, H. \& S. Gottwald (1995). Fuzzy Sets, Fuzzy Logic Fuzzy Methods. Chichester, UK: John Wiley \& Sons Ltd.

Bohórquez, P. \& S. Spronk (2003). International Migration in the Americas: Emerging Issues, Paper presented at the International Migration Conference in the Americas: Emerging Issues Conference, York University, UK.

Central Bank of El Salvador (2005). Retrieved April 1, 2005, from www.bcr.gob.sv

Cerioli, A. \& S. Zani (1990). Income and wealth distribution, inequality and poverty. Paper presented at Second International Conference on Income Distribution by Size: Generation, Distribution, Measurement and Applications, University of Pavia, Italy. 
Cheli, B. \& A. Lemmi (1995). A Totally Fuzzy and Relative Approach to the Multidimensional Analysis of Wellbeing. Economic Notes, 24, 115-134.

Chiappero Martinetti, E. (2000). A multidimensional assessment of well-being based on Sen's functioning approach, [Internet]. Available:

www.st-edmunds.cam.ac.uk/vhi/sen/papers/martinet.pdf [2005, 2 April 2005].

Doyal, L. \& I. Gough (1991). A theory of human need, London: Macmillan Press Ltd.

Foster, J., L. Lopez-Calva \& M. Szekely (2005). Measuring the Contribution of Human Development: methodology and an application to Mexico. Journal of Human Development, 6(1), 5-29.

Gallo, F., S. Mastrovita \& I. Siciliani (2004). To Be and To Feel Poor: A Latent Dimensions Analysis of the Deprivation. Paper presented at the General Conference of The International Organisation for Research in Income and Wealth, Cork, Ireland.

Harkness, S. (2004). Social and Political Indicators of Human Well-being: UNU-WIDER Research Paper No. 2004/33.

Hawthron, G. (ed.) (1993). The Standard of Living: The Tanner Lectures. Cambridge: Cambridge University Press.

IADB (Inter-American Development Bank \& Multilateral Investment Fund) (2004). Sending money home: Remittance to Latin America and the Caribbean, [Internet]. Available: http://www.iadb.org/publications/search.cfm?language=English\&topics=CMREM [2005, 13 April 2005].

Kandel, S. (2002). Migraciones, medio ambiente y pobreza rural en El Salvador. San Salvador: Fundación Prisma. 
Laderchi, C.R., R. Saith \& F. Stewart. (2003). Does it matter that we don't agree on the definition of poverty? A comparison of four approaches: Queen Elizabeth House Working Paper No. 107.

Lelli, S. (2001). Factor Analysis vs. fuzzy Sets Theory: Assessing the Influence of Different Techniques on Sen's Functioning Approach: CES Discussion Paper Series no 0121.

Ministry of Economics, General Direction of Statistics and Census (2005). Retrieved March 27, 2005, from www.digestyc.gob.sv

Nussbaum, M. (2000). Women and Human Development. Cambridge: Cambridge University Press.

Nussbaum, M. \& A. Sen (eds.). (1993). The Quality of Life. Oxford: Oxford University Press.

Orozco, M. (2002). Globalisation and Migration: The Impact of Family Remittances in Latin America. Latin American Politics and Society, 44(2),41-66.

Orozco, M. (2004). The Salvadoran diaspora: remittances, transnationalism and government, responses, [Internet]. Available:

http://www.thedialogue.org/publications/2004/summer/salvadoran_trpi.pdf $\quad[2005,14$ April 2005].

Pleitez Chávez, R.A. (2004). Remittances as a strategy to cope with systemic risk: panel results from rural households in El Salvador, Dissertation presented in Partial Fulfillment of the Requirement for the Degree Doctor of Philosophy in the Graduate School of The Ohio State, University. 
Quizilbash, M. (2002). A Note on the measurement of poverty and vulnerability in the South African context. Journal of International Development, 14, 757-772.

Ragin, C. (2000). Fuzzy-Set Social Science. Chicago: The University of Chicago Press.

Robeyns, I. (2003). Sen's Capability Approach and Gender Inequality: selecting relevant capabilities, Feminist Economics, 9(2-3), 61-92.

Robeyns, I. (2005). The Capability Approach: a theoretical survey. Journal of Human Development, 6(1).

Rosa, H. (2004). International Integration and the Environment in El Salvador: Working Group on Development and Environment in the Americas Discussion Paper no 7.

Sen, A. (1985). Commodities and Capabilities. Amsterdam: Elsevier Science Publishers BV

Sen, A. (1992). Inequality Reexamined. Harvard University Press: Cambridge, MA.

Sen, A. (1999). Development as Freedom. New York: Anchor books.

SIEMMES (Sistema de Información Estadística sobre las Migraciones en Mesoamérica) (2005). Retrieved April 25, 2005, from www.siemmes.iom.int

Taylor, J., C. Zabin \& K. Eckhoff (1999). Migration and rural development in El Salvador: a micro economy wide perspective. North American Journal of Economics and Finance, 10, 91-114.

UNDP (1990). Human Development Report 1990, New York: Oxford University Press. 
UNDP (2003). Informe sobre Desarrollo Humano El Salvador 2003, San Salvador: UNDP.

Zadeh, L. (1965). Fuzzy sets. Information and Control, 8, 338-353.

Zimmermann, H. (1987). Fuzzy Sets, Decision Making and Expert Systems, Boston: Kluwer Academic Publishers. 


\section{Appendix 1: The functioning categories and the related indicators}

\begin{tabular}{|c|c|c|c|c|}
\hline Category & \begin{tabular}{|l|} 
Sub- \\
category
\end{tabular} & Functioning/ resource & Ideal indicators & Feasible indicators \\
\hline \multirow{3}{*}{$\begin{array}{l}\text { 1. Life and } \\
\text { physical health }\end{array}$} & $\begin{array}{l}\text { 1.1. Life and } \\
\text { reproduction }\end{array}$ & $\begin{array}{l}\text { Functioning (being able to } \\
\text { live a long life) }\end{array}$ & $\begin{array}{l}\text { - Life expectancy at birth } \\
\text { - Infant/ neonatal mortality rate } \\
\text { Mortality rate of women at } \\
\text { childbirth }\end{array}$ & \\
\hline & \multirow[b]{2}{*}{$\begin{array}{l}\text { 1.2. Physical } \\
\text { Health }\end{array}$} & $\begin{array}{l}\text { Functioning (being able to } \\
\text { live a healthy life) }\end{array}$ & $\begin{array}{l}\text { - Incidence rates of main diseases } \\
\text { - Nourishment level }\end{array}$ & $\begin{array}{l}\text { Incidence rate of } 5 \text { groups of } \\
\text { diseases }\end{array}$ \\
\hline & & $\begin{array}{l}\text { Resource (having } \\
\text { opportunities to be } \\
\text { healthy) }\end{array}$ & $\begin{array}{l}\text { Do you have access to good } \\
\text { quality health care? }\end{array}$ & $\begin{array}{l}\text { Check up (resource } \neq \text { reflect } \\
\text { certain opportunity to have good } \\
\text { health) } \\
\text { - Are you insured? } \\
\text { - Distance to the nearest health } \\
\text { centre }\end{array}$ \\
\hline \multirow{6}{*}{$\begin{array}{l}\text { 2. Security, } \\
\text { shelter and } \\
\text { environment }\end{array}$} & \multirow[t]{2}{*}{ 2.1. Security } & $\begin{array}{l}\text { Functioning (enjoying a } \\
\text { secure life, free of external } \\
\text { dangers) }\end{array}$ & $\begin{array}{l}\text { How many times in the last year } \\
\text { have you been assaulted? } \\
\text { Do you feel you can walk in the } \\
\text { evening alone safely? }\end{array}$ & \\
\hline & & Resource & $\begin{array}{l}\text { How far is the nearest police } \\
\text { station? }\end{array}$ & - Phone for calling for help \\
\hline & \multirow{4}{*}{$\begin{array}{l}\text { 2.2. Shelter } \\
\text { and } \\
\text { environment }\end{array}$} & \multirow{2}{*}{$\begin{array}{l}\text { Resources (explaining } \\
\text { opportunities for health, } \\
\text { group interaction, } \text { etc.) }\end{array}$} & - Housing conditions & $\begin{array}{ll} & \text { House type } \\
- & \text { Crowding index } \\
- & \text { Cooking facilities } \\
\end{array}$ \\
\hline & & & - Access to basic services & $\begin{array}{ll}\text { - } & \text { Access to drinking water } \\
\text { - } & \text { Electricity } \\
\text { - } & \text { Sanitation system } \\
\end{array}$ \\
\hline & & $\begin{array}{l}\text { Functioning dimension } \\
\text { (together: having decent } \\
\text { and sustainable life } \\
\text { conditions) }\end{array}$ & $\begin{array}{l}\text { Do you live in harmony with the } \\
\text { environment? (Agriculture } \\
\text { practices, usage of recyclable } \\
\text { materials, reforestation, etc.) }\end{array}$ & \\
\hline & & Resources & $\begin{array}{l}\text { Are you aware of sustainable } \\
\text { agricultural practices? }\end{array}$ & $\begin{array}{l}\text { - Solid waste disposal } \\
\text { - Cooking }\end{array}$ \\
\hline \multirow{4}{*}{$\begin{array}{l}\text { 3. Education } \\
\text { and } \\
\text { knowledge }\end{array}$} & \multirow{2}{*}{$\begin{array}{l}\text { 3.1. } \\
\text { Education }\end{array}$} & $\begin{array}{l}\text { Functioning dimension } \\
\text { (being educated) }\end{array}$ & $\begin{array}{l}\text { - Literacy } \\
\text { - Level of education achieved }\end{array}$ & $\begin{array}{ll}\text { - } & \text { Literacy } \\
\text { - } & \text { Last level of education achieved }\end{array}$ \\
\hline & & \begin{tabular}{|l} 
Resources (having \\
opportunity to be \\
educated)
\end{tabular} & 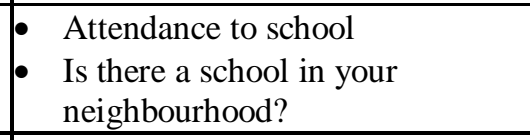 & 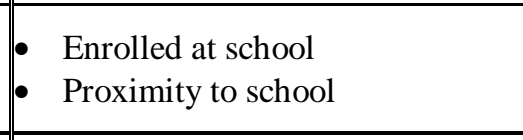 \\
\hline & \multirow{2}{*}{$\begin{array}{l}\text { 3.2. } \\
\text { Knowledge } \\
\text { and practical } \\
\text { reason }\end{array}$} & Functioning dimension & $\begin{array}{l}\text { How many books have you read } \\
\text { during the last year? }\end{array}$ & \\
\hline & & $\begin{array}{l}\text { Resources (having } \\
\text { opportunity to be } \\
\text { informed) }\end{array}$ & - Do you have access to news? & - Ownership of radio \\
\hline
\end{tabular}




\begin{tabular}{|c|c|c|c|c|}
\hline \multirow{8}{*}{$\begin{array}{l}\text { 4. Mental } \\
\text { well-being }\end{array}$} & \multirow{2}{*}{$\begin{array}{l}\text { 4.1. Mental } \\
\text { health }\end{array}$} & Functioning dimension & - Psychological assessment & \multirow[b]{2}{*}{$\begin{array}{l}\text { Indicator of working/ going to } \\
\text { school/at home by choice }\end{array}$} \\
\hline & & Resources & - Having a valuable activity & \\
\hline & \multirow{3}{*}{$\begin{array}{l}\text { 4.2. } \\
\text { Emotions }\end{array}$} & Functioning dimension & - Do you feel well? & $\begin{array}{l}\text { Why do you not study? } \\
\text { - What is your family situation? }\end{array}$ \\
\hline & & Functioning dimension & - Do you feel others respect you? & \\
\hline & & Resources & $\begin{array}{ll}\text { House ownership etc. (depends } \\
\text { on individual preferences) }\end{array}$ & - Do you own your house? \\
\hline & \multirow[b]{2}{*}{ 4.3. Security } & Functioning dimension & $\begin{array}{l}\text { Do you have economic security } \\
\text { (without remittances)? }\end{array}$ & \\
\hline & & Resources & $\begin{array}{l}\text { - Having a kind of protection } \\
\text { - Job security }\end{array}$ & $\begin{array}{ll}\text { - } & \text { Health insurance } \\
\text { Independent or dependent } \\
\text { employment }\end{array}$ \\
\hline & $\begin{array}{l}\text { 4.4 Leisure } \\
\text { activities }\end{array}$ & Resources & $\begin{array}{l}\text { Do you have access to leisure } \\
\text { activities, e.g. cinema, sports } \\
\text { facilities? }\end{array}$ & \\
\hline \multirow{3}{*}{$\begin{array}{l}\text { 5. Social } \\
\text { relations }\end{array}$} & \multirow[t]{2}{*}{$\begin{array}{l}\text { 5.1. } \\
\text { Friendship }\end{array}$} & $\begin{array}{l}\begin{array}{l}\text { Functioning dimension } \\
\text { (enjoying meaningful } \\
\text { relations with others) }\end{array} \\
\end{array}$ & $\begin{array}{l}\text { Do you receive support from } \\
\text { others when needed? }\end{array}$ & $\begin{array}{l}\text { Do you have daily social } \\
\text { contacts, e.g. at work? }\end{array}$ \\
\hline & & Resources & & - Do you have a phone? \\
\hline & \begin{tabular}{|l}
5.2. \\
Community \\
opportunities \\
\end{tabular} & $\begin{array}{l}\text { Resources (opportunity to } \\
\text { establish community ties) }\end{array}$ & - Having activities outside home & \\
\hline \multirow{4}{*}{$\begin{array}{l}\text { 6. Freedom of } \\
\text { choice and } \\
\text { action }\end{array}$} & $\begin{array}{l}\text { 6.1. Political } \\
\text { freedom }\end{array}$ & Functioning dimension & $\begin{array}{l}\text { Do you have freedom of } \\
\text { expression? }\end{array}$ & \\
\hline & \begin{tabular}{|l|} 
6.2. Self- \\
realisation
\end{tabular} & Functioning dimension & \begin{tabular}{|l} 
Are you satisfied with what you \\
do?
\end{tabular} & - Why do you not study? \\
\hline & \multirow{2}{*}{ 6.3. Other } & Functioning dimension & - Free mobility and time autonomy & Did you travel abroad? \\
\hline & & Resources & $\begin{array}{l}\text { Do you own a car or do you have } \\
\text { access to good public transport? }\end{array}$ & - Ownership \\
\hline
\end{tabular}




\section{Appendix 2: Membership functions used in our analysis}

\begin{tabular}{|c|c|c|c|}
\hline Variable & Dimension & $\begin{array}{l}\text { Choice of } \\
\text { membership } \\
\text { function }\end{array}$ & Details \\
\hline Health check-up & 1.2 & n.a. & $\begin{array}{l}\text { It is a binary variable so membership is only fully } \\
\text { complete or fully not. }\end{array}$ \\
\hline Health insurance & 1.2 & n.a. & It is a binary variable. \\
\hline Health index & 1.2 & Linear & $\begin{array}{l}\text { A person who did not show any health problems gets full } \\
\text { membership and somebody who is fatally ill no } \\
\text { membership. The in-between health statuses (light } \\
\text { diseases, chronic disease, and serious disease) are linearly } \\
\text { distributed. }\end{array}$ \\
\hline Health quality & 1.2 & Linear & $\begin{array}{l}\text { Health service rated as excellent gets full membership, } \\
\text { bad health service gets no membership and the in- } \\
\text { between categories are linearly distributed, because this } \\
\text { variable has equi-distributed categories. }\end{array}$ \\
\hline Time to hospital & 1.2 & Trapezoidal & $\begin{array}{l}\text { Any travelling time to the health centre longer than } 30 \\
\text { minutes gets no membership, as a health centre/ person } \\
\text { able to offer medical attention should be reached quickly } \\
\text { in cases of emergency. The membership values for a } \\
\text { travelling time between o and } 30 \text { minutes is linearly } \\
\text { calculated. }\end{array}$ \\
\hline If phone & 2.1 & n.a. & It is a binary variable. \\
\hline $\begin{array}{l}\text { Rooms/ household } \\
\text { member }\end{array}$ & 2.2 & Trapezoidal & $\begin{array}{l}\text { More than one rooms per household member (excluding } \\
\text { bathroom etc, see question 305) is more than sufficient, } \\
\text { especially in the Salvadoran context, these households } \\
\text { thus get full membership. For between zero and one } \\
\text { rooms we use a linear function to calculate membership. }\end{array}$ \\
\hline House type & 2.2 & $\begin{array}{l}\text { Subjective } \\
\text { discrete }\end{array}$ & $\begin{array}{l}\text { A freestanding house and apartment are considered full } \\
\text { membership and a tent gets no membership (an } \\
\text { unacceptable living condition). Renting a room }(3 \& 4) \\
\text { has a membership value of } 0.5 \text { (much worse than having } \\
\text { a whole house/ apartment) and living in a shed ( } 5 \& 6) \\
\text { gets a membership value of } 0.25 \text {. }\end{array}$ \\
\hline Toilet type & \begin{tabular}{|l|}
2.2 \\
\end{tabular} & $\begin{array}{l}\text { Subjective } \\
\text { discrete }\end{array}$ & $\begin{array}{l}\text { A sewer system gets full membership, whereas no } \\
\text { sanitary systems gets no membership. A private septic } \\
\text { tank and latrine get membership of } 0.75 \text {, whereas a } \\
\text { communal septic tank, sewer system and latrine get a } \\
\text { membership value of } 0.5 \text { (still much better than no } \\
\text { sanitary system). }\end{array}$ \\
\hline
\end{tabular}




\begin{tabular}{|c|c|c|c|}
\hline Solid waste disposal & 2.2 & $\begin{array}{l}\text { Subjective } \\
\text { discrete }\end{array}$ & $\begin{array}{l}\text { Communal and private garbage collection gets full } \\
\text { membership and disposal in a container gets a value of } \\
0.75 / \text { If the rubbish is buried it is much worse, so the } \\
\text { membership value is o.3. Burning is even worse and it } \\
\text { receives a membership value of } 0.15 \text {, which is not much } \\
\text { better than depositing the rubbish somewhere which gets } \\
\text { no membership. }\end{array}$ \\
\hline Lighting type & 2.2 & $\begin{array}{l}\text { Subjective } \\
\text { discrete }\end{array}$ & $\begin{array}{l}\text { Electricity gets full membership and a candle and other } \\
\text { lighting gets no membership. Lighting via a neighbour's } \\
\text { electivity gets a membership of } 0.75 \text {, as it still much } \\
\text { better than a kerosene lamp, especially by Salvadoran } \\
\text { standards. A kerosene lamp is only slightly better than a } \\
\text { candle and thus gets a membership value of } 0.25 \text {. }\end{array}$ \\
\hline Water access & 2.2 & $\begin{array}{l}\text { Subjective } \\
\text { discrete }\end{array}$ & $\begin{array}{l}\text { An indoor pipe gets full membership, whereas an outdoor } \\
\text { private pipe gets } 0.8 \text {, as this still gives the household an } \\
\text { independent source of relatively good water. A } \\
\text { neighbour's and public pipe both get } 0.6 \text {. Taking water } \\
\text { from a well or spring is much worse, as this is often of } \\
\text { bad quality. They thus get a membership of } 0.3 \text {. River } \\
\text { water is often very polluted in El Salvador and buying } \\
\text { water is very unreliable and uncertain They thus both get } \\
\text { no membership. }\end{array}$ \\
\hline Cooking facilities & 2.2 & $\begin{array}{l}\text { Subjective } \\
\text { discrete }\end{array}$ & $\begin{array}{l}\text { Cooking with electricity (very uncommon in El Salvador) } \\
\text { and with propane gas and kerosene get full membership } \\
\text { as they are acceptable ways of cooking in El Salvador. } \\
\text { Cooking with firewood and coal gets a much lower } \\
\text { membership value of } 0.3 \text { as it is harmful for the health of } \\
\text { the population and the environment. No cooking } \\
\text { possibility obviously gets no membership. }\end{array}$ \\
\hline Time to school & 3.1 & Trapezoidal & $\begin{array}{l}\text { Any travelling time higher than } 60 \text { minutes one way gets } \\
\text { no membership as this will seriously discourage students } \\
\text { from attending school. Membership values for travelling } \\
\text { times between zero to } 60 \text { minutes are linearly distributed. }\end{array}$ \\
\hline Literacy & 3.1 & n.a. & It is a binary variable. \\
\hline Education level & 3.1 & Relative & $\begin{array}{l}\text { The education level aimed at and needed in different } \\
\text { societies and cultures is socially determined (this is } \\
\text { something else than basic literacy, which everyone should } \\
\text { have), therefore we use a relative frequency distribution } \\
\text { membership function, ranging from no education to } \\
\text { special education. }\end{array}$ \\
\hline School enrolment & 3.1 & n.a. & It is a binary variable. \\
\hline Daily activity & 4.1 & n.a. & It is a binary variable. \\
\hline House ownership & 4.2 & Relative & $\begin{array}{l}\text { We use the house ownership variable as a measure for } \\
\text { social respect; therefore we use a relative frequency } \\
\text { distribution to calculate membership, ranging from being } \\
\text { a house-owner to tenant farmer. }\end{array}$ \\
\hline Why not study & 4.2 & n.a. & It is a binary variable. \\
\hline
\end{tabular}




\begin{tabular}{|l|l|l|l|}
\hline Family status & 4.2 & Relative & $\begin{array}{l}\text { Family status is partly socially determined (e.g. whether it } \\
\text { is socially acceptable to just life together as opposed to } \\
\text { being married). Therefore we opt for a relative frequency } \\
\text { distribution membership function, ranging from widowed } \\
\text { to married. }\end{array}$ \\
\hline Employment type & 4.3 & Relative & $\begin{array}{l}\text { How happy one is with the type of employment one has } \\
\text { also depends on others, for example if all neighbours are } \\
\text { also temporary employees, one can still feel satisfied. } \\
\text { Therefore it is appropriate to use relative frequency } \\
\text { distribution function to calculate membership, ranging } \\
\text { from being an employer to household employee. }\end{array}$ \\
\hline If contract & 4.3 & n.a. & It is a binary variable. \\
\hline Social contact & 2.1 & n.a. & It is a binary variable. \\
\hline
\end{tabular}




\section{Appendix 3: The aggregation methods used in our analysis}

1.1 Health check-up

1.2 Health insurance

1.2 Health index

1.2 Time to hospital

1.2 Health service quality
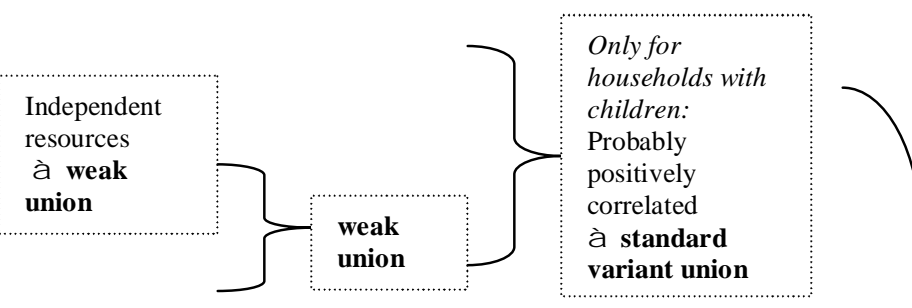

2.1 If phone

2.2 House type

2.2 Crowding index

2.2 Lighting type

2.2 Water access

2.2 Toilet type

2.2 Cooking facilities

2.2 Waste disposal

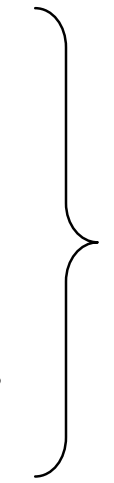

Possibly positive correlation between these indicators (if freestanding house, probably more rooms/ person, better cooking facilities etc.) ‡ standard variant

intersection

3.1 Literacy

3.1 Education level

3.1 School enrolment

3.1 Time to school

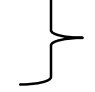

3.2 If radio

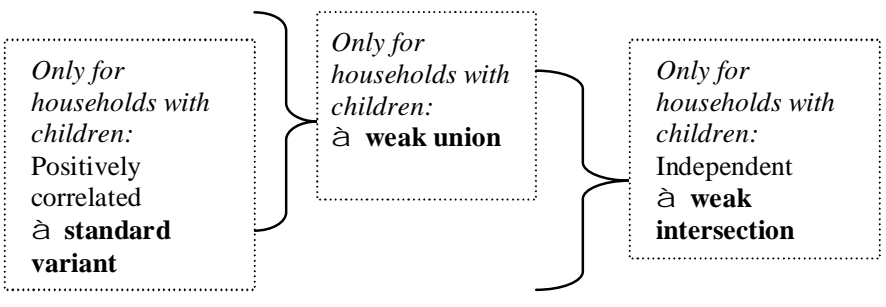

Only for

households with

ndependent

‡ weak

Not possible due to too low observations

4.1 Daily activity

4.2 House ownership

4.2 Why not study

4.2 Family status

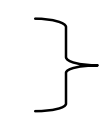

4.3 Employment type

4.3 If contract
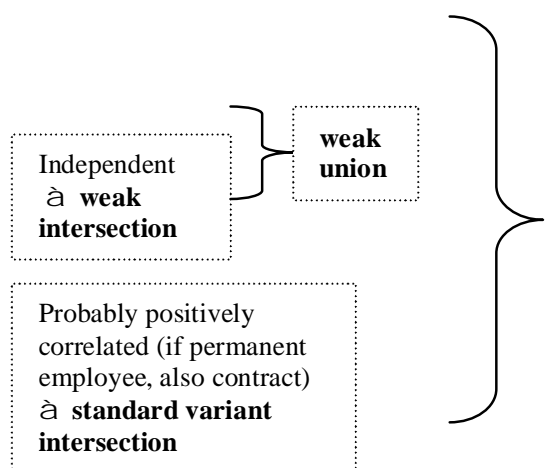

Independent

$\ddagger$ weak

intersection

5.1 If phone

5.2 Social contact

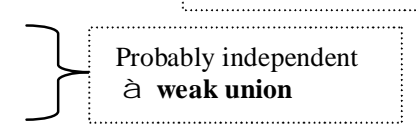




\section{Appendix 4: Indicator and dimension membership degrees for sample}

Indicators

\begin{tabular}{|c|c|c|c|c|c|c|c|c|c|c|}
\hline 1 & $\mathrm{Hea}$ & check & & ance & & alth & Healt & quality & Hosl & l travel \\
\hline$\mu$ & Freq. & Percent & Freq. & Percent & Freq. & Percent & Freq. & Percent & Freq. & Percent \\
\hline $0-0.1$ & 47,169 & 85.06 & 68,606 & 95.71 & & & 1,363 & 8.10 & 7,834 & 46.58 \\
\hline $0.11-0.2$ & & & & & & & 161 & 0.96 & 480 & 2.85 \\
\hline $0.21-0.3$ & & & & & 29 & 0.04 & 4,327 & 25.73 & & \\
\hline $0.31-0.4$ & & & & & & & 437 & 2.60 & 1,885 & 11.21 \\
\hline $0.41-0.5$ & & & & & 202 & 0.28 & 9,302 & 55.30 & 2,442 & 14.52 \\
\hline $0.51-0.6$ & & & & & & & 52 & 0.31 & & \\
\hline $0.61-0.7$ & & & & & 777 & 1.08 & 73 & 0.43 & 2,312 & 13.75 \\
\hline $0.71-0.8$ & & & & & & & 699 & 4.16 & 57 & 0.34 \\
\hline $0.81-0.9$ & & & & & 8,537 & 11.91 & 6 & 0.04 & 1,702 & 10.12 \\
\hline $0.91-1$ & 8,288 & 14.94 & 3,077 & 4.29 & 62,138 & 86.68 & 400 & 2.38 & 108 & 0.64 \\
\hline Total & 55,457 & 100.00 & 71,683 & 100.00 & 71,683 & 100.00 & 16,820 & 100.00 & 16,820 & 100.00 \\
\hline mean & \begin{tabular}{|l|l|}
0.15 \\
\end{tabular} & & 0.043 & & 0.98 & & 0.44 & & 0.37 & \\
\hline
\end{tabular}

\begin{tabular}{|c|c|c|c|c|c|c|c|c|c|c|c|c|c|c|c|c|}
\hline 2 & \multicolumn{2}{|c|}{ Phone } & \multicolumn{2}{|c|}{ Rooms/ HH member } & \multicolumn{2}{|c|}{ House } & \multicolumn{2}{|c|}{ Toilet } & \multicolumn{2}{|c|}{ Lighting } & \multicolumn{2}{|c|}{ Water } & \multicolumn{2}{|c|}{ Waste } & \multicolumn{2}{|c|}{ Cooking } \\
\hline$\mu$ & Freq. & Percent & Freq. & Percent & Freq. & Percent & Freq. & Percent & Freq. & Percent & Freq. & Percent & Freq. & Percent & Freq. & Percent \\
\hline $0-0.1$ & 43,877 & 61.21 & 953 & 1.33 & 2,199 & 3.07 & 6,968 & 9.72 & 3,409 & 4.76 & 11,748 & 16.39 & 12,234 & 17.07 & 1,297 & 1.81 \\
\hline $0.11-0.2$ & & & 8,786 & 12.26 & & & & & & & & & 27,177 & 37.91 & & \\
\hline $0.21-0.3$ & 14 & 0.02 & 11,744 & 16.38 & 308 & 0.43 & & & 8,274 & 11.54 & & & & & & \\
\hline $0.31-0.4$ & & & 7,297 & 10.18 & & & & & & & & & 3,077 & 4.29 & 27,426 & 38.26 \\
\hline $0.41-0.5$ & & & 12,238 & 17.07 & 2,655 & 3.70 & 5,207 & 7.26 & & & & & & & & \\
\hline $0.51-0.6$ & & & 2,827 & 3.94 & & & & & & & & & & & & \\
\hline $0.61-0.7$ & & & 6,208 & 8.66 & & & & & & & 17,263 & 24.08 & & & & \\
\hline $0.71-0.8$ & & & 2,779 & 3.88 & & & 40,973 & 57.16 & 5,739 & 8.01 & & & 1,528 & 2.13 & & \\
\hline $0.81-0.9$ & 24,432 & 34.08 & 4,746 & 6.62 & & & & & & & 24,332 & 33.94 & & & & \\
\hline $0.91-1$ & 3,360 & 4.69 & 14,105 & 19.68 & 66,521 & 92.80 & 18,535 & 25.86 & 54,261 & 75.70 & 18,340 & 25.58 & 27,667 & 38.60 & 42,960 & 59.93 \\
\hline Total & 71,683 & 100.00 & 71,683 & 100.00 & 71,683 & 100.00 & 71,683 & 100.00 & 71,683 & 100.00 & 71,683 & 100.00 & 71,683 & 100.00 & 71,683 & 100.00 \\
\hline mean & .41 & & .57 & & 95 & & .76 & & .86 & & .75 & & .51 & & .75 & \\
\hline
\end{tabular}




\begin{tabular}{|c|c|c|c|c|c|c|c|c|}
\hline 3 & Schoo & travel & & racy & Educa & on level & Enroln & nt level \\
\hline$\mu$ & Freq. & $\%$ & Freq. & $\%$ & Freq. & $\%$ & Freq. & $\%$ \\
\hline $0-0.1$ & 1,528 & 2.91 & 2,482 & 3.46 & 19,414 & 27.38 & 42,246 & 68.64 \\
\hline $0.11-0.2$ & 33 & 0.06 & & & & & & \\
\hline $0.21-0.3$ & 660 & 1.26 & & & & & & \\
\hline $0.31-0.4$ & 354 & 0.68 & & & & & & \\
\hline $0.41-0.5$ & 4,957 & 9.45 & 30,139 & 42.04 & & & & \\
\hline $0.51-0.6$ & 895 & 1.71 & & & & & & \\
\hline $0.61-0.7$ & 4,094 & 7.81 & & & & & & \\
\hline $0.71-0.8$ & 10,160 & 19.38 & & & 40,329 & 56.87 & & \\
\hline $0.81-0.9$ & 14,455 & 27.57 & & & & & & \\
\hline $0.91-1$ & 15,299 & 29.18 & 39,062 & 54.49 & 11,173 & 15.76 & 19,302 & 31.36 \\
\hline Total & 52,435 & 100.00 & 71,683 & 100.00 & 70,916 & 100.00 & 61,548 & 100.00 \\
\hline mean & .76 & & .76 & & .64 & & .31 & \\
\hline
\end{tabular}

\begin{tabular}{|c|c|c|c|c|c|c|c|c|c|c|c|c|}
\hline \multirow{2}{*}{$\begin{array}{ll} & 4 \\
\mu & \\
\end{array}$} & \multicolumn{2}{|c|}{ Activity } & \multicolumn{2}{|c|}{ House ownership } & \multicolumn{2}{|c|}{ Why not studying } & \multicolumn{2}{|c|}{ Family status } & \multicolumn{2}{|c|}{ Employment type } & \multicolumn{2}{|c|}{ Contract } \\
\hline & Freq. & $\%$ & Freq. & $\%$ & Freq. & $\%$ & Freq. & $\%$ & Freq. & $\%$ & Freq. & $\%$ \\
\hline $0-0.1$ & 8,502 & 13.83 & 1,441 & 2.01 & 62,328 & 87.16 & 3,040 & 5.99 & 1,628 & 3.07 & 10,739 & 77.44 \\
\hline $0.11-0.2$ & & & 10,640 & 14.84 & & & 5,962 & 11.75 & & & & \\
\hline $0.21-0.3$ & & & 3,737 & 5.21 & & & & & 9,986 & 18.86 & & \\
\hline $0.31-0.4$ & & & 7,061 & 9.85 & & & & & & & & \\
\hline \multicolumn{13}{|l|}{$0.41-0.5$} \\
\hline $0.51-0.6$ & & & & & & & 18,680 & 36.82 & 20,111 & 37.98 & & \\
\hline $0.61-0.7$ & & & & & & & & & 355 & 0.67 & & \\
\hline $0.71-0.8$ & & & & & & & 10,762 & 21.21 & & & & \\
\hline \multicolumn{13}{|l|}{$0.81-0.9$} \\
\hline $0.91-1$ & 52,974 & 86.17 & 48,804 & 68.08 & 9,184 & 12.84 & 12,291 & 24.23 & 20,875 & 39.42 & 3,129 & 22.56 \\
\hline Total & 61,476 & 100.00 & 71,683 & 100.00 & 71,512 & 100.00 & 50,735 & 100.00 & 52,955 & 100.00 & 13,868 & 100.00 \\
\hline mean & .86 & & .77 & & .13 & & .66 & & .69 & & .23 & \\
\hline
\end{tabular}

\section{Dimensions:}

\begin{tabular}{|l|ll|}
\hline \multicolumn{1}{|c|}{$\mathbf{5}$} & \multicolumn{2}{|c|}{ Social activity } \\
\hline$\mu$ & Freq. & $\%$ \\
\hline $0-0.1$ & 54,373 & 88.15 \\
\hline $0.11-0.2$ & \\
\hline $0.21-0.3$ & \\
\hline $0.31-0.4$ & \\
\hline $0.41-0.5$ & \\
\hline $0.51-0.6$ & \\
\hline $0.61-0.7$ & \\
\hline $0.71-0.8$ & \\
\hline $0.81-0.9$ & \\
\hline $0.91-1$ & 7,310 \\
\hline Total & 61,683 & \\
\hline mean & $\mathbf{. 1 2}$ \\
\hline
\end{tabular}

\begin{tabular}{|c|c|c|c|c|c|c|c|c|c|c|}
\hline \multirow[b]{2}{*}{$\mu$} & \multicolumn{2}{|c|}{1} & \multicolumn{2}{|r|}{2} & \multicolumn{2}{|c|}{3} & \multicolumn{2}{|c|}{4} & \multicolumn{2}{|c|}{5} \\
\hline & Freq. & $\%$ & Freq. & $\%$ & Freq. & $\%$ & Freq. & $\%$ & Freq. & $\%$ \\
\hline $0-0.1$ & & & 48,190 & 67.23 & 28,032 & 44.12 & 6,667 & 78.71 & 32,726 & 53.06 \\
\hline $0.11-0.2$ & & & 5,883 & 8.21 & & & 256 & 3.02 & & \\
\hline $0.21-0.3$ & & & 861 & 1.20 & 2 & 0.00 & 623 & 7.36 & 12 & 0.02 \\
\hline $0.31-0.4$ & & & 1,542 & 2.15 & & & 17 & 0.20 & & \\
\hline $0.41-0.5$ & & & 1,781 & 2.48 & 6,165 & 9.70 & & & & \\
\hline $0.51-0.6$ & 11 & 0.08 & 782 & 1.09 & 2 & 0.00 & 198 & 2.34 & & \\
\hline $0.61-0.7$ & 49 & 0.34 & 2,380 & 3.32 & 38 & 0.06 & 17 & 0.20 & & \\
\hline $0.71-0.8$ & 82 & 0.56 & 2,981 & 4.16 & 288 & 0.45 & 12 & 0.14 & & \\
\hline $0.81-0.9$ & 1,545 & 10.62 & 5,857 & 8.17 & 5,620 & 8.84 & & & 19,102 & 30.97 \\
\hline $0.91-1$ & 12,856 & 88.40 & 1,426 & 1.99 & 23,393 & 36.82 & 680 & 8.03 & 9,843 & 15.96 \\
\hline Total & 14,543 & 100.00 & 71,683 & 100.00 & 63,540 & 100.00 & 8,470 & 100.00 & 61,683 & 100.00 \\
\hline mean & .99 & & .26 & & .54 & & .2 & & .49 & \\
\hline
\end{tabular}




\section{Appendix 5: Indicator and dimension average membership degrees for certain groups}

Indicators:

\begin{tabular}{|c|c|c|c|c|c|c|c|c|c|c|c|c|c|c|c|c|c|c|c|c|c|c|c|c|}
\hline & 1a & $1 b$ & 1c & 1.4 & 1d & $2 a$ & $2 \mathrm{~b}$ & $2 c$ & $2 d$ & $2 e$ & $2 f$ & $2 \mathrm{~g}$ & $2 \mathrm{~h}$ & $3 a$ & $3 \mathbf{b}$ & $3 c$ & 3d & $4 a$ & $4 b$ & $4 c$ & $4 d$ & $4 e$ & $4 f$ & $5 a$ \\
\hline \multicolumn{25}{|c|}{ Urban/rural } \\
\hline Urban & .17 & .068 & .97 & .42 & .38 & .45 & .62 & .95 & .83 & .95 & .81 & .75 & .87 & .76 & .83 & .66 & .4 & .87 & .69 & .12 & .6 & .7 & .28 & .14 \\
\hline Rural & .13 & .017 & .97 & .4 & .22 & .19 & .44 & .94 & .62 & .75 & .54 & .2 & .56 & .76 & .68 & .48 & .23 & .85 & .8 & .13 & .61 & .56 & .16 & .092 \\
\hline All & .15 & .043 & .97 & .41 & .3 & .32 & .53 & .95 & .72 & .85 & .67 & .47 & .71 & .76 & .76 & .57 & .31 & .86 & .75 & .13 & .61 & .63 & .23 & .12 \\
\hline \multicolumn{25}{|l|}{ Region } \\
\hline West & .15 & .033 & .97 & .41 & .28 & .26 & .51 & .95 & .7 & .79 & .64 & .38 & .65 & .76 & .74 & .55 & .28 & .86 & .74 & .14 & .62 & .59 & .16 & .11 \\
\hline Central 1 & .14 & .04 & .97 & .41 & .27 & .28 & .52 & .94 & .72 & .87 & .64 & .45 & .74 & .76 & .77 & .59 & .32 & .87 & .77 & .11 & .61 & .64 & .22 & .12 \\
\hline Central 2 & .13 & .027 & .97 & .41 & .27 & .25 & .46 & .94 & .67 & .82 & .6 & .37 & .61 & .77 & .72 & .53 & .28 & .85 & .8 & .13 & .61 & .58 & .19 & .098 \\
\hline East & .14 & .033 & .96 & .42 & .34 & .34 & .49 & .95 & .66 & .8 & .66 & .38 & .67 & .78 & .68 & .47 & .28 & .82 & .79 & .17 & .58 & .58 & .14 & .11 \\
\hline $\begin{array}{l}\text { San } \\
\text { Salvador }\end{array}$ & .19 & .095 & .98 & .41 & .35 & .54 & .71 & .96 & .91 & .97 & .88 & .89 & .95 & .73 & .89 & .75 & .45 & .91 & .59 & .093 & .62 & .76 & .38 & .16 \\
\hline All & .15 & .043 & .97 & .41 & .3 & .32 & .53 & .95 & .72 & .85 & .67 & .47 & .71 & .76 & .76 & .57 & .31 & .86 & .75 & .13 & .61 & .63 & .23 & .12 \\
\hline \multicolumn{25}{|c|}{ Household size } \\
\hline $1-3$ & .43 & .12 & .96 & .42 & $*$ & .3 & .7 & .93 & .72 & .86 & .7 & .52 & .72 & $*$ & .79 & .59 & .42 & .82 & .66 & .28 & .57 & .64 & .23 & .29 \\
\hline $4-6$ & .15 & .033 & .97 & .42 & $*$ & .35 & .56 & .95 & .74 & .86 & .7 & .51 & .76 & $*$ & .79 & .61 & .38 & .89 & .74 & .1 & .64 & .65 & .24 & .099 \\
\hline$>7$ & .06 & $\begin{array}{l}.002 \\
7 \\
\end{array}$ & .97 & .4 & * & .27 & .35 & .95 & .69 & .8 & .6 & .35 & .61 & $*$ & .66 & .47 & .16 & .84 & .83 & .061 & .59 & .57 & .19 & .015 \\
\hline All & .15 & .043 & .97 & .41 & $*$ & .32 & .53 & .95 & .72 & .85 & .67 & .47 & .71 & $*$ & .76 & .57 & .31 & .86 & .75 & .13 & .61 & .63 & .23 & .12 \\
\hline \multicolumn{25}{|c|}{ Gender of household head } \\
\hline Male & .16 & .051 & .97 & .41 & $*$ & .31 & .52 & .95 & .72 & .84 & .66 & .46 & .7 & $*$ & .76 & .6 & .3 & .87 & .75 & .12 & .69 & .64 & .23 & .12 \\
\hline Female & .13 & .023 & .96 & .42 & $*$ & .34 & .55 & .95 & .74 & .86 & .7 & .51 & .74 & $*$ & .74 & .5 & .36 & .83 & .75 & .16 & .41 & .6 & .21 & .12 \\
\hline All & .15 & .043 & .97 & .41 & $*$ & .32 & .53 & .95 & .72 & .85 & .67 & .47 & .71 & $*$ & .76 & .57 & .31 & .86 & .75 & .13 & .61 & .63 & .23 & .12 \\
\hline \multicolumn{25}{|c|}{ Age category of household head } \\
\hline $16-25$ & .49 & .088 & .98 & .39 & $*$ & .17 & .54 & .89 & .62 & .78 & .63 & .41 & .7 & $*$ & .84 & .7 & .091 & .92 & .51 & .086 & .69 & .61 & .22 & .26 \\
\hline $26-55$ & .12 & .045 & .97 & .41 & $*$ & .32 & .52 & .95 & .72 & .85 & .67 & .48 & $\begin{array}{l}.73 \\
\end{array}$ & $*$ & .79 & .63 & .32 & .93 & .73 & .094 & .63 & .64 & .23 & .12 \\
\hline 56-70 & .13 & .027 & .96 & .41 & $*$ & .37 & .54 & .97 & .75 & .86 & .68 & .47 & .69 & $*$ & .67 & .42 & .36 & .73 & .85 & .21 & .56 & .58 & .21 & .083 \\
\hline$>70$ & .13 & .025 & .95 & .46 & $*$ & .32 & .58 & .97 & .74 & .85 & .68 & .47 & .64 & $*$ & .58 & \begin{tabular}{|l|}
.29 \\
\end{tabular} & .39 & .32 & .84 & .3 & .5 & .55 & .17 & .048 \\
\hline All & .15 & .043 & .97 & .41 & * & .32 & .53 & .95 & .72 & .85 & .67 & .47 & .71 & $*$ & .76 & .57 & .31 & .86 & .75 & .13 & .61 & .63 & .23 & .12 \\
\hline
\end{tabular}


Legend:

1a: Health check

$1 b$ : Insurance

1c Health

1d: Health quality

1e: Hospital travel

2a: Phone

2b: Rooms/ HH member

2c: House 2d: Toilet

2e: Lighting

2f: Water access

2g: Waste disposal

2h: Cooking

3a: School travel

3b: Literacy

3c: Education level 3d: Enrolment rate

4a: Activity

4b: House ownership

4c: Why not studying

4d: Family status

4e: Employment

4f: Contract

5a: Social activity

Dimensions:

\begin{tabular}{|c|c|c|c|c|c|}
\hline & 1 & 2 & 3 & 4 & 5 \\
\hline \multicolumn{6}{|c|}{ Urban/rural } \\
\hline Urban & .98 & .31 & .53 & .14 & .54 \\
\hline Rural & .97 & .044 & .46 & .085 & .27 \\
\hline All & .98 & .18 & .5 & .12 & .41 \\
\hline \multicolumn{6}{|l|}{ Region } \\
\hline West & .98 & .13 & .48 & .078 & .35 \\
\hline Central 1 & .98 & .14 & .52 & .11 & .38 \\
\hline Central 2 & .98 & .1 & .47 & .093 & .33 \\
\hline East & .98 & .14 & .46 & .076 & .42 \\
\hline $\begin{array}{l}\text { San } \\
\text { Salvador }\end{array}$ & .99 & .43 & .55 & .19 & .62 \\
\hline All & .98 & .18 & .5 & .12 & .41 \\
\hline \multicolumn{6}{|c|}{ Household size } \\
\hline $1-3$ & .98 & .19 & .51 & .099 & .51 \\
\hline $4-6$ & .98 & .21 & .51 & .13 & .43 \\
\hline$>7$ & .98 & .1 & .47 & .086 & .29 \\
\hline All & .98 & .18 & .5 & .12 & .41 \\
\hline \multicolumn{6}{|c|}{ Gender of household head } \\
\hline Male & .98 & .17 & .51 & .12 & .4 \\
\hline Female & .97 & .19 & .46 & .1 & .43 \\
\hline All & .98 & .18 & .5 & .12 & .41 \\
\hline \multicolumn{6}{|c|}{ Age category of household head } \\
\hline $16-25$ & .99 & .089 & .45 & .11 & .4 \\
\hline $26-55$ & .98 & .18 & .51 & .12 & .4 \\
\hline $56-70$ & .97 & .2 & .48 & .11 & .43 \\
\hline$>70$ & .96 & .17 & .46 & .074 & .35 \\
\hline All & .98 & .18 & .5 & .12 & .41 \\
\hline
\end{tabular}




\section{Appendix 6: Indicator's and dimension's average membership degrees for different remittances groups}

\section{Indicators:}

\begin{tabular}{|c|c|c|c|c|c|c|c|c|c|c|c|c|c|c|c|c|c|c|c|c|c|c|c|c|}
\hline & $1 \mathrm{a}$ & $1 \mathrm{~b}$ & $1 \mathrm{c}$ & 1.4 & 1d & $2 a$ & $2 \mathbf{b}$ & $2 c$ & $2 d$ & $2 e$ & $2 f$ & $2 \mathrm{~g}$ & $2 \mathrm{~h}$ & $3 \mathbf{a}$ & $3 \mathbf{b}$ & $3 c$ & 3d & $4 a$ & $4 b$ & $4 c$ & $4 d$ & $4 e$ & $\mathbf{4 f}$ & $5 a$ \\
\hline \multicolumn{25}{|l|}{ If member abroad } \\
\hline Yes & .13 & .022 & .96 & .43 & .31 & .55 & .61 & .98 & .77 & .92 & .72 & .5 & .79 & .77 & .74 & .5 & .37 & .76 & .82 & .2 & .52 & .63 & .24 & .063 \\
\hline No & .15 & .047 & .97 & .41 & .3 & .27 & .51 & .94 & .71 & .83 & .66 & .47 & .7 & .76 & .76 & .58 & .3 & .88 & .73 & .11 & .63 & .63 & .22 & .13 \\
\hline All & .15 & .043 & .97 & .41 & .3 & .32 & .53 & .95 & .72 & .85 & .67 & .47 & .71 & .76 & .76 & .57 & .31 & .86 & .75 & .13 & .61 & .63 & .23 & .12 \\
\hline \multicolumn{25}{|l|}{ If remittances } \\
\hline Yes in cash & .14 & .017 & .97 & .43 & .31 & .51 & .59 & .98 & .76 & .91 & .71 & .49 & .78 & .77 & .73 & .51 & .35 & .76 & .8 & .19 & .53 & .62 & .19 & .064 \\
\hline Yes in kind & .23 & .12 & .97 & .43 & .4 & .46 & .67 & .91 & .77 & .94 & .77 & .63 & .92 & .79 & .88 & .72 & .37 & .92 & .66 & .14 & .65 & .74 & .17 & .17 \\
\hline Yes both & .15 & .028 & .95 & .44 & .37 & .62 & .66 & .98 & .8 & .93 & .77 & .58 & .88 & .78 & .79 & .6 & .42 & .78 & .76 & .19 & .52 & .67 & .28 & .07 \\
\hline No & .15 & .049 & .97 & .4 & .29 & .26 & .51 & .94 & .71 & .83 & .66 & .46 & .69 & .76 & .76 & .58 & .3 & .88 & .73 & .11 & .63 & .63 & .23 & .13 \\
\hline All & .15 & .043 & .97 & .41 & .3 & .32 & .53 & .95 & .72 & .85 & .67 & .47 & .71 & .76 & .76 & .57 & .31 & .86 & .75 & .13 & .61 & .63 & .23 & .12 \\
\hline \multicolumn{25}{|c|}{ Frequency of remittances } \\
\hline $\begin{array}{l}\text { Half-yearly to } \\
\text { yearly }\end{array}$ & .16 & .042 & .96 & .42 & .35 & .38 & .56 & .95 & .71 & .86 & .69 & .51 & .74 & .77 & .8 & .6 & .34 & .87 & .72 & .099 & .61 & .62 & .14 & .12 \\
\hline $\begin{array}{l}\text { Monthly to half- } \\
\text { yearly }\end{array}$ & .14 & .024 & .95 & .43 & .36 & .38 & .61 & .98 & .76 & .9 & .69 & .54 & .77 & .76 & .74 & .52 & .5 & .82 & .82 & .16 & .54 & .58 & .26 & .12 \\
\hline $\begin{array}{l}\text { Every } 2 \text { weeks to } \\
\text { monthly }\end{array}$ & .14 & .017 & .96 & .44 & .32 & .54 & .61 & .98 & .77 & .92 & .72 & .5 & .8 & .77 & .74 & .52 & .35 & .75 & .79 & .2 & .53 & .63 & .2 & .057 \\
\hline $\begin{array}{l}\text { More often than } \\
\text { every } 2 \text { weeks }\end{array}$ & .083 & .038 & .94 & .3 & .31 & .48 & .63 & .97 & .71 & .87 & .73 & .54 & .8 & .77 & .83 & .61 & .35 & .84 & .72 & .12 & .51 & .71 & .68 & .097 \\
\hline All & .14 & .019 & .96 & .43 & .33 & .53 & .61 & .98 & .76 & .92 & .72 & .5 & .79 & .77 & .74 & .52 & .36 & .76 & .79 & .19 & .53 & .63 & .2 & .065 \\
\hline \multicolumn{25}{|c|}{ Amount of remittances } \\
\hline$\$ 100$ or less & .15 & .022 & .96 & .42 & .33 & .43 & .57 & .97 & .74 & .88 & .69 & .46 & .75 & .77 & .73 & .52 & .34 & .79 & .78 & .16 & .55 & .61 & .19 & .088 \\
\hline$\$ 101$ to $\$ 250$ & .13 & .018 & .97 & .44 & .31 & .58 & .61 & .98 & .76 & .94 & .72 & .51 & .81 & .77 & .73 & .5 & .36 & .73 & .8 & .22 & .52 & .64 & .16 & .048 \\
\hline$\$ 251$ to $\$ 500$ & .13 & .0089 & .96 & .47 & .34 & .67 & .65 & .99 & .82 & .97 & .78 & .58 & .86 & .77 & .77 & .54 & .41 & .73 & .81 & .2 & .5 & .67 & .31 & .036 \\
\hline$\$ 501$ to $\$ 1000$ & .11 & .02 & .98 & .41 & .26 & .68 & .75 & 1 & .83 & .97 & .82 & .62 & .87 & .78 & .81 & .63 & .37 & .61 & .85 & .17 & .58 & .71 & .61 & .024 \\
\hline$\$ 1001$ to $\$ 2500$ & 0 & 0 & 1 & .38 & 0 & .85 & .86 & 1 & .84 & 1 & .91 & .61 & .94 & .83 & .89 & .66 & 1 & .67 & .85 & .24 & .54 & .98 & 0 & 0 \\
\hline$\$ 2501$ and more & 0 & 0 & 1 & & & 1 & 1 & 1 & 1 & 1 & .91 & 1 & 1 & .84 & 1 & .95 & .45 & 1 & .26 & .55 & .78 & .76 & 0 & 0 \\
\hline All & .14 & .018 & .96 & .44 & .32 & .52 & .6 & .98 & .76 & .92 & .72 & .5 & .79 & .77 & .74 & .52 & .36 & .76 & .79 & .19 & .53 & .63 & .21 & .065 \\
\hline
\end{tabular}

Legend as in Appendix 8 
Dimensions:

\begin{tabular}{|l|l|l|l|l|l|}
\hline \multicolumn{7}{|l|}{} & $\mathbf{1}$ & $\mathbf{2}$ & $\mathbf{3}$ & $\mathbf{4}$ & $\mathbf{5}$ \\
\hline If member abroad & .97 & .26 & .5 & .15 & .58 \\
\hline Yes & .98 & .16 & .49 & .11 & .37 \\
\hline No & .98 & .18 & .5 & .12 & .41 \\
\hline All & .97 & .24 & .5 & .12 & .55 \\
\hline If remittances & .98 & .31 & .5 & .14 & .58 \\
\hline Yes in cash & .97 & .33 & .48 & .16 & .65 \\
\hline Yes in kind & .98 & .15 & .49 & .11 & .36 \\
\hline Yes both & .98 & .18 & .5 & .12 & .41 \\
\hline No & \multicolumn{5}{|l|}{} \\
\hline All & .97 & .23 & .42 & .13 & .46 \\
\hline Frequency of remittances & .97 & .22 & .48 & .017 & .46 \\
\hline Half-yearly to yearly & .97 & .26 & .51 & .13 & .57 \\
\hline Monthly to half-yearly & .97 & .29 & .32 & .54 & .56 \\
\hline Every 2 weeks to monthly & .97 & .26 & .5 & .13 & .56 \\
\hline More often than every 2 weeks & .97 & .2 & .47 & .11 & .48 \\
\hline All & .97 & .26 & .51 & .073 & .6 \\
\hline Amount of remittances & .96 & .35 & .54 & .22 & .69 \\
\hline \$100 or less & .98 & .39 & .6 & .46 & .7 \\
\hline \$101 to \$250 & 1 & .51 & .54 &. & .85 \\
\hline \$251 to \$500 &. & .91 & 1 & 0 & 1 \\
\hline \$501 to \$1000 & .97 & .25 & .5 & .13 & .56 \\
\hline \$1001 to \$2500 & & \\
\hline \$2501 and more & & \\
\hline All & \multicolumn{5}{|l|}{} \\
\hline
\end{tabular}

\section{Remittances spent on housing}

\begin{tabular}{|l|l|l|l|l|l|l|l|}
\hline \multicolumn{1}{|c|}{ Amount spent } & $\begin{array}{c}\text { Rooms/ } \mathrm{HH} \\
\text { member }\end{array}$ & House & Toilet & Lighting & Water & Cooking & 2 \\
\hline None & .6 & .98 & .76 & .91 & .72 & .79 & .25 \\
\hline$\$ 100$ or less & .64 & .98 & .85 & .94 & .82 & .94 & .4 \\
\hline$\$ 101$ to $\$ 250$ & .74 & .97 & .78 & .98 & .86 & 1 & .45 \\
\hline$\$ 251$ to $\$ 500$ & .93 & 1 & .95 & .94 & .81 & .87 & .67 \\
\hline$\$ 1001$ to $\$ 2500$ & .4 & 1 & .75 & 1 & .8 & .3 & .15 \\
\hline All & .61 & .98 & .76 & .92 & .72 & .79 & .26 \\
\hline
\end{tabular}

\section{Remittances spent on education}

\begin{tabular}{|l|l|l|l|l|l|}
\hline \multicolumn{1}{|c|}{ Amount spent } & School travel & Literacy & Education level & Enrolment level & 3 \\
\hline None & .78 & .74 & .52 & .34 & .5 \\
\hline$\$ 100$ or less & .74 & .8 & .58 & .48 & .49 \\
\hline$\$ 101$ to $\$ 250$ & .73 & .85 & .66 & .82 & .37 \\
\hline$\$ 251$ to $\$ 500$ & .75 & .83 & .59 & .66 & .65 \\
\hline$\$ 1001$ to $\$ 2500$ & .83 & 1 & .92 & 1 & 1 \\
\hline \$2501 and more & .92 & 1 & .97 & 0 & .36 \\
\hline All & .77 & .74 & .52 & .5 \\
\hline
\end{tabular}




\section{Maastricht Graduate School of Governance Working Paper Series}

\section{List of publications}

\begin{tabular}{|c|c|c|}
\hline $\begin{array}{l}2006 \\
\text { No. }\end{array}$ & Author(s) & Title \\
\hline 001 & $\begin{array}{l}\text { Gassmann, F. and } \\
\text { G. Notten }\end{array}$ & $\begin{array}{l}\text { Size matters: Poverty reduction effects of means-tested and } \\
\text { universal child benefits in Russia }\end{array}$ \\
\hline 002 & $\begin{array}{l}\text { Hagen-Zanker, J. } \\
\text { and } \\
\text { M.R. Muñiz Castillo }\end{array}$ & $\begin{array}{l}\text { Exploring multi-dimensional wellbeing and remittances in } \\
\text { El Salvador }\end{array}$ \\
\hline 003 & Augsburg, B. & $\begin{array}{l}\text { Econometric evaluation of the SEWA Bank in India: } \\
\text { Applying matching techniques based on the propensity } \\
\text { score }\end{array}$ \\
\hline 004 & $\begin{array}{l}\text { Notten, G. and } \\
\text { D. de Crombrugghe ( }\end{array}$ & Poverty and consumption smoothing in Russia \\
\hline
\end{tabular}

2007

\begin{tabular}{|c|c|c|}
\hline No. & Author(s) & Title \\
\hline 001 & $\begin{array}{l}\text { Notten, G. and C. de } \\
\text { Neubourg }\end{array}$ & $\begin{array}{l}\text { Relative or absolute poverty in the US and EU? The battle } \\
\text { of the rates }\end{array}$ \\
\hline 002 & $\begin{array}{l}\text { Hodges, A. A. } \\
\text { Dufay, K. Dashdorj, } \\
\text { K.Y. Jong, T. } \\
\text { Mungun and U. } \\
\text { Budragchaa }\end{array}$ & $\begin{array}{l}\text { Child benefits and poverty reduction: Evidence from } \\
\text { Mongolia's Child Money Programme }\end{array}$ \\
\hline 003 & $\begin{array}{l}\text { Hagen-Zanker, J. } \\
\text { and Siegel, M. }\end{array}$ & The determinants of remittances: A review of the literature \\
\hline 004 & Notten, G. & $\begin{array}{l}\text { Managing risks: What Russian households do to smooth } \\
\text { consumption }\end{array}$ \\
\hline 005 & $\begin{array}{l}\text { Notten, G. and C. de } \\
\text { Neubourg }\end{array}$ & $\begin{array}{l}\text { Poverty in Europe and the USA: Exchanging official } \\
\text { measurement methods }\end{array}$ \\
\hline 006 & $\begin{array}{l}\text { Notten, G and C. de } \\
\text { Neubourg }\end{array}$ & $\begin{array}{l}\text { The policy relevance of absolute and relative poverty } \\
\text { headcounts: Whats in a number? }\end{array}$ \\
\hline 007 & $\begin{array}{l}\text { Hagen-Zanker, J. } \\
\text { and M. Siegel }\end{array}$ & $\begin{array}{l}\text { A critical discussion of the motivation to remit in Albania } \\
\text { and Moldova }\end{array}$ \\
\hline 008 & Wu, Treena & $\begin{array}{l}\text { Types of Households most vulnerable to physical and } \\
\text { economic threats: Case studies in Aceh after the Tsunami } \\
\text { (Theme 2) }\end{array}$ \\
\hline
\end{tabular}

